This is an electronic reprint of the original article. This reprint may differ from the original in pagination and typographic detail.

Author(s): Mauno, Saija; Cheng, Ting; Lim, Vivian

Title: $\quad$ The Far-Reaching Consequences of Job Insecurity : A Review on Family-Related Outcomes

Year: $\quad 2017$

Version:

Please cite the original version:

Mauno, S., Cheng, T., \& Lim, V. (2017). The Far-Reaching Consequences of Job Insecurity : A Review on Family-Related Outcomes. Marriage and Family Review, 53(8), 717-743. https://doi.org/10.1080/01494929.2017.1283382

All material supplied via JYX is protected by copyright and other intellectual property rights, and duplication or sale of all or part of any of the repository collections is not permitted, except that material may be duplicated by you for your research use or educational purposes in electronic or print form. You must obtain permission for any other use. Electronic or print copies may not be offered, whether for sale or otherwise to anyone who is not an authorised user. 


\title{
The Far-Reaching Consequences of Job Insecurity: A Review on Family-Related Outcomes
}

\author{
Saija Mauno \\ Department of Psychology, University of Jyväskylä, Jyväskylä, FI \\ School of Social Sciences and Humanities (Psychology), University of Tampere, Finland \\ Ting Cheng \\ Department of Psychology, University of Jyväskylä, Jyväskylä, FI \\ Vivian Lim \\ Department of Management \& Organization, NUS business School, National University of \\ Singapore, Singapore
}

Address correspondence to Saija Mauno. E-mail: saija.mauno@jyu.fi

\begin{abstract}
Job insecurity (JI) appears a fairly stable job stressor in working life today and likely to impair employee well-being. This review article presents the key findings of studies examining the effects of perceived JI on family well-being (e.g., marital/parental role quality, work-family conflict). The results, based on 25 published peer-reviewed studies, suggest an association between JI and impaired family well-being. Thus, JI spills over into family life as proposed in the spillover theory of work-family interface. Furthermore, studies have found some evidence of crossover effects of
\end{abstract}


JI from parents to children: parents' JI relates to negative outcomes in children. These results support the view that JI is very likely a severe stressor not only for employees' well-being and health but also for their families' well-being. Limitations, future directions and implications are also discussed.

Keywords: crossover, family outcomes, job insecurity, qualitative review, spillover

\section{INTRODUCTION}

Job insecurity (henceforth $J I$ ) is defined as a "perceived potential loss of continuity in a job situation that can span the range from permanent loss of the job itself to loss of some subjectively important features of the job" (Greenhalgh \& Rosenblatt, 1984, p. 440). JI has been identified as a job stressor which is negatively related to employees' work attitudes and health-related outcomes (for meta-analyses, see Cheng \& Chan, 2008; Sverke, Hellgren, \& Näswall, 2002). Earlier research has mostly focused on the consequences of JI for individual employees and organizations, with less attention devoted to examining its impact on the family. This paper reviews (qualitatively) studies examining the impact of JI on individuals' family-related outcomes. The starting point of our study is the observation that JI is perhaps more common nowadays than ever before due to continuously accelerating globalization and digitalization and organizations' pursuit of greater effectiveness and cost-cutting. All this typically means increased JI for employees, and this may well have negative implications for their family well-being/other family-related outcomes.

\section{Theoretical Frameworks: COR, Spillover and Crossover Theories}

Three theoretical models help to explain how and why JI would affect the family domain, namely the Conservation of Resources model (COR theory; Hobfoll, 1989, 2001), the spillover model (e.g., Barling, 1990; Lambert, 1990; see also Kinnunen, Rantanen, Mauno, \& Peeters, 2014) 
and the crossover model (e.g., Kinnunen, Rantanen, \& Mauno, 2013; Westman, Etzion, \& Danon, 2001). These theoretical frameworks and their particular relevance within the scope of this review are next introduced.

\section{Conservation of Resources (COR) Theory}

The main tenet of COR theory (Hobfoll, 1989, 2001) is that individuals strive to obtain and conserve resources, be either material (e.g., incomes) or immaterial, typically referring to various psychosocial resources an individual possesses. From the perspective of well-being and health (in various life domains), it is important to note that in COR theory both of these are considered to be crucial psychosocial resources. Moreover, COR theory also proposes that losing resources may result in more detrimental consequences than gaining new resources. Such a resource loss may appear stressful, implying that COR theory is also a stress theory. In fact, the threat of losing some important resources may have equally detrimental health (or other negative) effects than the actual loss of this resource. According to this reasoning, the threat of losing one's job can be considered as stressful as an actual job loss (real resource loss) because the former presents a threat of anticipated resource loss. More importantly, COR theory also argues that resource losses are likely to accumulate, forming spirals. Considering JI, this implies that JI as a primary threat of resource loss (a starting point for resource losses) may result in poorer family well-being (an endpoint of resource losses). However, this relationship can also be indirect, suggesting that JI first impairs an employee's occupational well-being (e.g., job satisfaction, burnout as a more proximal outcome), constituting a secondary resource loss. Impaired occupational well-being, in turn, impacts negatively on an employee's family well-being (e.g., marital or parental satisfaction as a more distal outcome), signifying a third resource loss as an endpoint of resource losses originating from 
JI. This kind of accumulative resource loss is known in COR theory as a spiral of resource losses (Hobfoll, 1989, 2001).

In this review, we conceive of COR theory as an overall stress theory, explaining why JI can be hypothesized to be stressful for individuals in the first place. Furthermore, we propose that the basic ideas of COR theory (e.g., hypothesizing spirals of resource losses) are implicitly also present in spillover and crossover theories on work-family interface, which are the key theoretical models applied in this review.

\section{Spillover Theory}

Spillover theory suggests that work and family experiences are interconnected (see Kinnunen, Mäkikangas, Mauno, De Cuyper, \& De Witte, 2014; Lambert, 1990). Fundamentally, spillover theory relies on a holistic view of an individual's life where life events and experiences in different domains affect each other. Emotions and behaviors at work spill over into the family domain and vice versa because of the similarity of these experiences and behaviors. Thus, spillover is a bidirectional phenomenon, meaning that experiences at work (e.g., job stressors) spill over to family life (e.g., marital dissatisfaction) but also family experiences (e.g., family stressors) may spill over to work (e.g., job dissatisfaction). In this review, we focus on spillover effects in a workto-family direction since we study one particular job stressor (JI). In a work-to-family direction, most typical manifestations of spillover effects have included impaired parenting behaviors (e.g., punitive parenting) or marital role quality (e.g., withdrawal from family interactions, marital dissatisfaction) (e.g., Crouter \& McHale, 1993; Hughes \& Galinsky, 1994; Mauno \& Kinnunen, 1999a; Porfeli, Wang, \& Hartung, 2008; Repetti \& Wood, 1997). Noteworthy is also that empirical studies on spillover have typically examined within-individuals experiences, that is, how the work experience of an employee relates to his/her family-related well-being without examining 
between-individual effects (i.e., a transmission of experiences between individuals/significant others).

Many scholars have suggested that spillover may be direct or indirect (Frone, 2003; Kinnunen et al., 2014; Lambert, 1990; Mauno \& Kinnunen, 1999a). A direct spillover occurs when, for instance, a job stressor directly impacts an employee's family well-being, whereas indirect spillover occurs through mediators. For example, a job stressor (a predictor) first causes an employee to experience poorer occupational well-being (e.g., job dissatisfaction, a mediator), which, in turn, relates to poorer family well-being (e.g., marital dissatisfaction, an outcome). In this example, occupational well-being acts as a mediator because it shares the same context as a stressor (work). It is noteworthy that similar reasoning was already presented in relation to COR theory, implying that in our approach the spillover model can be conceived of as a specific manifestation of the COR model, that is, how the basic ideas of COR theory (spirals of resource losses) can be applied to explain and understand the interface between work and family life.

Regarding JI, the spillover model suggests that JI, as a job stressor (as a primary anticipated resource loss), is most likely to affect family well-being indirectly, via the various stress reactions (mediators) it causes within an employee (see Zhao, Lim, \& Teo, 2012). Indeed, JI may trigger various stress reactions in employees (subsequent resource losses in the form of occupational or overall impaired well-being), such as anxiety, depression, concentration problems, fatigue, irritability, or dissatisfaction (for reviews, see Cheng \& Chan, 2008; Sverke et al., 2002). These overall stress reactions, or resource losses defined in the context of the COR model, very likely spill over into an employee's family domain in the form of an individual's negative family/parental/marital experiences, implying accumulating resource losses in family well-being (or other relevant family-related outcomes) as an endpoint of this spillover process. In this view of 
spillover effects, resource losses form chains, where certain losses may also mediate the relationship between other losses.

One often studied mediator in the spillover process is work-family conflict, describing a role conflict between work and family, manifesting as a form of time-, strain-, or behavior-based conflict (see more, Greenhaus \& Beutell, 1985). Specifically, the integrative model of work-family interface (Frone, 2003; Frone, Russell, \& Cooper, 1992) suggests that various job stressors including JI - first exacerbate work-family conflict, which then leads to impaired well-being in other life domains, including family. Some scholars have even considered JI itself as a role stressor at work (Jacobson, 1991), thereby suggesting an association between JI and work-family conflict which is, by definition, a role conflict (Greenhaus \& Beutell, 1985).

However, sometimes work-family conflict has been considered as a family-related outcome itself (not a mediator) when investigating spillover effects from work to family. Nevertheless, it should be noted that work-family conflict is not purely a family-related experience and thus not a 'real family outcome', yet it clearly differs from the occupational and overall wellbeing outcomes of JI, the results of which have already been reviewed (Cheng \& Chan, 2008; Sverke et al. 2002). Consequently, as work-family conflict is connected with family experiences and as it differs from other (occupational, overall) indicators of well-being, we included workfamily conflict as one indicators of family-level outcome in this review. It is noteworthy that we also found empirical studies on work-family conflict studied as a family-related outcome of JI, and for this reason it had to be included in our review.

Specifically, in this review, we consider both approaches: (a) work-family conflict as a mediator between JI and family outcomes (as suggested by Frone, 2003; Frone et al., 1992) and (b) work-family conflict as a direct outcome of JI (itself indicating family-related effects). 
Since work-family conflict is also a bidirectional experience (Frone, 2003; Frone et al., 1992; Kinnunen et al., 2014) we consider both of these directions, that is, work-to-family (WFC; work interferes with family) and family-to-work conflict (FWC; family interferes with work). Furthermore, some of the studies reviewed also adopted a bidirectional approach (e.g., Kinnunen \& Mauno, 1998; Voydanoff, 2005) and examined the effects of JI on both directions of workfamily conflict. From now on, WFC refers to work-to-family and FWC family-to-work conflict.

\section{Crossover Theory}

The effects of JI may also be transmitted from the employee to significant others (partner or children), a transmission process defined as crossover, proposing that work experiences are transmitted (i.e., crossed over) between individuals. Indeed, crossover refers to the betweenindividual effects of work-family interface. Here we perceive crossover as an extension of the spillover model explaining particularly why and how job stressors (like JI) are transmitted between significant others. Specifically, the crossover model proposes that various (work) experiences can be transmitted or crossed over between the significant others and, in the family, specifically from spouse to spouse or from parent to child(ren) (e.g., Kinnunen et al., 2013; Westman et al., 2001). Here, this means that JI experienced by an employee, affects the family members by impairing their well-being, satisfaction or performance due to the fact that an employee transfers his/her jobrelated worries to his/her spouse/partner or children (Kinnunen et al., 2013; Mauno \& Kinnunen, 1999a; Westman et al., 2001; Zhao et al., 2012). Crossover occurs because emotional contagion

(e.g., via empathy) is very likely in close relationships and because family is a shared social context for family members (Kinnunen et al., 2013; Levy \& Nail, 1993; Westman et al., 2001). Thus, both social interaction and context similarity enable crossover processes. As in spillover, the crossover process may be indirectly mediated through an employee's diminished well-being, satisfaction, 
performance, or work-family conflict, which then affects other family member(s), causing them to experience impaired well-being, satisfaction or performance, or other negative reactions.

Applied to JI, the crossover hypothesis proposes that JI, as an anticipated resource loss, may first impair an employee's occupational or overall well-being (a secondary resource loss; similar to what we described in relation to spillover and COR theories), which then transmits to his/her spouse/partner causing feelings of diminished well-being or marital satisfaction or other negative feelings (an endpoint of resource loss spreading from one person to another). However, it is possible that JI also affects the family well-being of one's partner/children directly, that is, without mediators. In this review, we consider both direct and indirect crossover effects.

To conclude, as was the case in the spillover process described earlier, so too in the crossover process we can hypothesize a resource loss spiral starting from JI, which then directly or indirectly (via mediators; in the form of subsequent resource losses) has a negative effect on family well-being/other family-related outcomes, constituting an endpoint of resource losses occurring in the family domain. The main difference from the spillover process is that in the crossover process these resource losses are transmitted from an employee (a sender) to his/her spouse/partner or children (a receiver). The overall idea of accumulative resources losses has clear underpinnings in COR theory, which in this review is connected with the spillover and crossover theories on work-family interface.

The main goal of this review study is to examine, first, whether JI spills over into an employee's family-related outcomes (a within-individual design), and, second, whether JI crosses over from an employee (a sender) to his/her marital partner and/or children (a receiver), affecting family-related (or other relevant) outcomes in the partner and/or children. Potential mediators and moderators in these relationships (spillover, crossover) are also analyzed and reported. 


\section{METHODS}

\section{Literature Search and Inclusion Criteria}

Based on a search of databases such as PsycINFO, PsycArticles, and ProQuest Psychology Journals using the following keywords: 'job/economic insecurity' plus one of the following: 'family', 'work-family conflict', 'work-family interference', 'work-family enrichment/facilitation/balance', 'marital', 'parent/parental', 'mother', 'father', or 'child', relevant studies were identified. Only quantitative empirical studies published in peer-reviewed journals in English were included. Qualitative studies were excluded as we found no published qualitative studies on this topic and focusing on JI as defined here. JI had to be measured using a perceived JI operationalization either as a form of threat of job loss (one-dimensional, global definition) or as a perceived threat of losing other valued job characteristics (multi-dimensional definition). In total, 25 published studies met these inclusion criteria. These studies were read, then classified into two groups: the first group focusing on the spillover effects of JI on family outcomes $(\mathrm{n}=16$ studies,

Table 1), and the second group on the crossover effects of JI either between spouses or between parent(s) and child(ren) $(\mathrm{n}=9$ studies, Table 2$)$. The spillover and crossover theories described in the introduction guided this classification. It is noteworthy that many of the reviewed studies examined other work stressors besides JI (of the spillover studies 10/16 and of the crossover studies 3/9), but the findings summarized in Tables 1 and $\mathbf{2}$ concentrate on the effects of JI on family outcomes. Studies were reviewed narratively for the two following reasons: (1) we wanted to provide a rich description of all results also focusing on potential mediator and moderator effects, which would have been impossible to analyze meta-analytically due to the small numbers of such studies, (2) to the best of our knowledge, this is the first review of the relationships between 
perceived JI and family-related outcomes, demanding a rich description of the results, allowing us also to perceive their limitations more fully and to propose directions for future research in the field.

\section{RESULTS}

\section{Spillover Relationships Between JI and Family-Related Outcomes}

Table 1 summarizes the key findings on the family-related outcomes of JI from the spillover perspective (16 studies). These studies mostly explored whether JI relates to increased work-family conflict (WFC/FWC; in eight studies) or poorer marital role quality (e.g., marital satisfaction, marital tension, marital adjustment; in 6 studies). Fewer studies examined the relationships between JI and indicators of positive work-family interface (3 studies on work-family enrichment/facilitation/balance; on definitions of enrichment/facilitation/balance, see e.g., Kinnunen et al., 2014) or negative parenting (e.g., family functioning, participation in child-related activities, parental stress; four studies). Mediator relationships, most typically with work-family conflict as a mediator, were examined in six studies and moderator relationships in three studies (work characteristics, coping strategies, or parental/job involvement, age as moderators). About half of the studies sampled American (6) or Canadian (1) workers, and another half North European workers (five Finland, two Netherlands, and one Sweden). Average sample size was 1030 (ranging from 120 to 2764 employees) and data were analyzed either by regression analysis (11 studies) or structural equation modeling (SEM, five studies). Only three studies were longitudinal and six studies focused specifically on JI.

Out of 16 studies, 15 reported a significant relationship between JI and family-related outcomes (significant correlations but not robust effects were reported by Roeters, van der Lippe, 
\& Kluwer, 2010). The studies mostly showed that JI was related to higher WFC (Batt \& Valcour, 2003; Beham \& Drobnic, 2009; Hughes, Galinsky, \& Morris, 1992; Richter, Näswall, \& Sverke, 2010; Ruokolainen, Mauno, \& Cheng, 2014; Voydanoff, 2004, 2005) and FWC (Kinnunen \& Mauno, 1998; Voydanoff, 2007). Studies on the experiences of positive work-family interface reported that JI was also associated with lower work-to-family enrichment (over-time effect if baseline of enrichment was not taken into account; Cheng, Mauno, \& Lee, 2014a), lower work-tofamily facilitation (only if other work characteristics were not taken into account, Voydanoff, 2005), and lower satisfaction with work-family balance (via WFC as a mediator; Beham \& Drobnic, 2009). Furthermore, JI was found to be associated with poorer marital role quality (Barling \& Macewen, 1992; Cheng, Mauno, \& Lee, 2014b; Hughes \& Galinsky, 1994; Hughes et al., 1992; Larson, Wilson, \& Beley, 1994; Mauno \& Kinnunen, 1999a; see Table 2) in the form of marital dissatisfaction, marital tension, and poorer marital adjustment. Finally, JI was related to parenting behaviors through overall poorer family functioning (Larson et al., 1994), negative work spillover into parenthood (in mothers; Mauno \& Kinnunen, 1999b), parent's slighter participation in child-related activities (in fathers; Roeters, van der Lippe, \& Kluwer, 2009) as well as higher parental stress and parental dissatisfaction (Ruokolainen et al., 2014).

In these studies, mediator analyses showed that WFC mediated the relationship between JI and family outcomes such as marital tension (Hughes et al., 1992) and employees' satisfaction with work-family balance (Beham \& Drobnic, 2009), and FWC (Voydanoff, 2005). Moreover, moderator analyses revealed that some work characteristics, e.g., high job commitment/engagement, rendered employees more vulnerable to the harmful role of JI in family (parental dissatisfaction; Ruokolainen et al., 2014). Some coping strategies (symptom reduction 
coping) made employees less vulnerable to the adverse role of JI in emotional energy level at home (Cheng et al. 2014b).

Earlier studies on JI have suggested that the effects of JI on well-being may be different for men and women (Cheng \& Chan, 2008; Sverke et al., 2002). For this reason we analyzed gender differences also in relation to family well-being/outcomes. A few of the studies reviewed revealed interesting gender differences in family-related outcomes. Thus, gender moderated the relationships between JI and family well-being. Kinnunen and Mauno (1998) showed that JI was related to lower (not higher) WFC only in women, maybe because women attach greater importance to family roles and consequently JI does not increase but rather decrease their WFC. On the other hand, the same authors found later in a longitudinal study (Mauno \& Kinnunen, 1999b) that JI had a prolonged effect on negative work spillover into parenthood only in women. Relying on an American sample, Larson et al. (1994) reported also more family-related effects of JI in women than in men. However, a more recent Swedish study (Richter et al., 2010) indicated that perceived workload mediated the relationship between JI and WFC only in men, supporting a traditional view that JI may be more harmful for men because job role is more salient for men, making them more vulnerable to JI. Also one Dutch study (Roeters et al., 2009) found that JI was more detrimental for fathers, implying less participation in child-related activities in fathers. However, overall the findings on gender differences seem not to be fully consistent.

\section{Conclusions and Future Challenges as Regards Spillover Studies}

The selected studies indicated in general that JI was positively related to WFC, FWC and negatively to marital role quality. We also found some evidence of its detrimental relationships with employees' parenting behaviors and attitudes, and with decreased positive work-family 
interface (lower work-family enrichment/facilitation/balance). Overall, the findings supported the hypotheses of COR theory (Hobfoll, 1989, 2001) and also those of the spillover model (e.g., Kinnunen et al., 2014; Lambert, 1990). On the other hand, longitudinal evidence was mostly lacking and limited to Nordic countries (Cheng et al., 2014a; Mauno \& Kinnunen, 1999b; Richter et al., 2010). Some other longitudinal studies have shown that JI may also be a persistent longlasting stressor (Kinnunen et al., 2014; Mauno, Leskinen, \& Kinnunen, 2001). However, the effects of persistent JI on family outcomes have not yet been explored.

Furthermore, by focusing predominantly on work-family conflict (typically WFC) as a mediator between JI and family outcomes, the range of mediators examined was quite limited. Other types of mediators such as occupational well-being (e.g., job satisfaction, job burnout) deserve more attention in future studies. It is plausible that proxy well-being (proxy outcomes of JI include occupational well-being and attitudes to work) mediates the associations between JI and family outcomes, the idea of which has also been highlighted in the spillover theory (Lambert, 1990). It is also surprising that potential moderators were so little studied. Thus, the question, among whom or under what circumstances JI is most likely or most strongly associated with negative family outcomes, has to be answered in future. Moderators have received attention in examining job-related and overall consequences of JI (Cheng \& Chan, 2008) but rarely in investigating family outcomes. Furthermore, the results on moderators seem to be rather inconsistent. For instance, concerning gender; some studies suggest that JI is more detrimental (for family well-being) in women, whereas others propose the opposite (for men). Thus, gender as a moderator between JI and family-related outcomes deserves more attention in future studies. Also, an employee's trait-like resources, such as self-efficacy, big five dimensions, or generic coping strategies, could either strengthen or weaken the relationship between JI and family outcomes, thus 
acting as moderators. Other interesting moderators would include other demographic factors besides gender, e.g., socioeconomic status, career history, job contract, family situation, or spouse's employment status.

\section{Crossover Relationships Between JI and Family-Related Outcomes}

The key findings of the studies focusing on the family outcomes of JI from a crossover perspective are summarized in Table 2 (nine studies). Seven studies examined crossover from parents to children, and six of them also found significant relationships (the only exception is Stewart \& Barling, 1996). Two studies investigated crossover relationships between working couples (Mauno \& Kinnunen, 1999a; Westman et al., 2001), but yielded non-significant results on crossover. Two studies were longitudinal and data in all studies were analyzed using structural equation modeling (SEM). Six studies focused particularly on JI as an antecedent of family outcomes. Mediators were investigated in seven studies (i.e., children's perceptions of parental JI, children's beliefs in an unjust world, children's negative mood, children's cognitive difficulties, parent's money anxiety, job exhaustion, psychosomatic symptoms, other parental job-related affects, and parenting behaviors) and moderators (i.e., gender and identification with mother/father) in three studies. Samples were relatively small, the average sample size being 171 (ranging from 120 to 215 respondents/typically dyads), which is a small sample size in quantitative non-experimental research but relatively common in crossover designs, when more than one informant is used. Four studies sampled Canadian, three Singaporean, one Finnish and one Israel participants.

The studies generally suggested that parental JI was transmitted to their children, i.e., adolescents (Barling, Dupre, \& Hepburn, 1998; Barling \& Mendelson, 1999; Barling, Zacharatos, 
\& Hepburn, 1999; Lim \& Loo, 2003; Lim \& Sng, 2006; Zhao et al., 2012). Specifically, six of seven studies found that parental JI was associated with children's poorer well-being (mood; Barling \& Mendelson, 1999; self-efficacy; Lim \& Loo, 2003; Zhao et al. 2012) and poorer school performance (grade performance; Barling \& Mendelson, 1999; Barling et al., 1999). In addition, four studies indicated that parental JI was related to children's poorer academic performance and vocational motivation, such as work beliefs (Barling et al., 1998), work motivation (Barling et al., 1998; Lim \& Loo, 2003, Lim \& Sng, 2006) and poorer justice perceptions (Barling \& Mendelson, 1999). Interestingly, four studies found that children were able to sense their parents' experiences of JI (Barling et al., 1998, 1999; Barling \& Mendelson, 1999; Lim \& Loo, 2003), suggesting that at least older children are competent observers of their parents' JI.

Mediator analyses yielded interesting results. A set of Canadian studies revealed that children's perceptions of their fathers' JI were associated with children's negative work beliefs, which, in turn, were linked to their negative work attitudes (alienation from work; Barling et al., 1998). Moreover, among those children identifying strongly with their fathers this negative association was even stronger. However, this moderator relationship (identification with father/mother) was not found in mother-to-child relationships. Another Canadian study by Barling and Mendelson (1999), reported that children's perceptions of their parents' JI was first associated with believing world as an unjust and negative mood (in children), which was then related to children's poorer school performance. Children's cognitive difficulties also served as a mediator between children's perceptions of parent's JI and school performance (Barling et al., 1999).

In a non-western context, Lim and co-workers (Lim \& Loo, 2003; Lim \& Sng, 2006, Zhao et al., 2012) conducted three studies examining the effect of parents' JI on children. Lim and Loo (2003) reported that fathers' JI was positively related, while mothers' JI was negatively related to 
authoritarian parenting behaviors (parenting behaviors that are insensitive, unsupportive and punishment-focused). Interestingly, only mothers' authoritarian parenting was associated with children's lower self-efficacy. In a later study, Lim and colleagues (Zhao et al., 2012) examined the mediating relationships of three types of career-specific parenting behaviors: lack of engagement, support, and interference in the relationship between fathers' JI and offspring's career self-efficacy. They found that JI (reported by fathers) was associated with a lack of engagement and support (reported by children). Moreover, the relationship between paternal JI and offspring's career self-efficacy was mediated by a lack of engagement with sons and by a lack of support for daughters. Thus, this study provided an initial and interesting glimpse of the effects of paternal JI on sons and daughters. Fathers suffering from JI were less likely to provide career-related support to their daughters, which in turn was related to lower levels of career self-efficacy for the latter. Fathers perceiving JI were less likely to engage in their sons' career development. Sons who perceived fathers' lack of engagement tended to have lower levels of career self-efficacy. In addition, Lim and Sng (2006) also showed earlier, in a separate study, that paternal JI was linked to paternal money anxiety, whereas maternal JI was not related to maternal money anxiety. Parents' money anxiety was associated with offspring's money anxiety, which, in turn, was related to their negative money motives and thereafter to lower intrinsic work motivation.

Overall, crossover studies reveal some notable gender difference in crossover relationships between JI and family-related well-being. Some studies show that fathers' JI seems to exert a stronger crossover relationship concerning children compared to mothers' JI (e.g., Barling et al., 1998; Zhao et al., 2012). Gender role expectations could be one plausible explanation for these findings: men usually view themselves as and are expected by society to be the primary providers for their families (Barling et al., 1998). Because JI instills a sense of uncertainty and powerlessness, 
fathers may experience a feeling of inadequacy in their roles as economic providers. A potential lack of work arising from JI may give rise to anxiety and negative emotions in fathers, leading them to engage in poorer parenting behaviors when interacting with their children. An alternative explanation for the gender differences in the crossover effects of JI could be that mothers are able to compartmentalize home and work, thus, skillfully preventing negative work experiences such as JI from affecting their parenting behaviors and interactions with their children.

\section{Conclusions and Future Challenges as Regards Crossover Studies}

Our review indicates that there is empirical evidence supporting the negative relationship between parental JI and children's well-being, motivation, and school performance. Thus, JI crosses over from parents to children. This finding is also consistent with COR theory (Hobfoll, 1989 , 2001), proposing a hypothesis on resource loss spirals which may well originate in JI as an anticipated resource loss. On the other hand, this evidence comes only from two countries (Canada, Singapore) and is mostly cross-sectional. As in spillover studies, longer follow-ups from a crossover perspective are totally lacking. Thus, we do not yet know whether parental JI has longerlasting effects on children's subsequent career success or well-being. Since JI is a fairly permanent stressor in today's working life, more effort is required to examine its long-term consequences on the family. In addition, it seems that moderators have been less examined than mediators. The findings concerning moderators were not very consistent, which may suggest that quite dissimilar moderators have been studied. This limitation also concerned spillover studies discussed earlier. However, it is plausible that factors besides gender such as parental socioeconomic status, career success, well-being or their trait-like personality characteristics moderate the relationships between parents' JI and their children. 
Somewhat surprisingly, no empirical evidence was found for the crossover of JI between couples. Even though JI may be a shared experience in the marital relationship (Mauno \& Kinnunen, 2002; Westman et al., 2001), this does not mean that it necessarily moves from one spouse to the other. Nevertheless, it has to be noted that crossover between couples was explored in only two studies (Finland, Israel), and generalizations would be premature. Crossover between couples has already been studied quite extensively in work-family research (for a review, see Kinnunen et al., 2013) but not concerning JI. As in spillover studies, researchers should pay more attention to mediating processes in examining couples and their JI because, for example, occupational well-being (e.g., job satisfaction, job burnout) may act as a mediator in such crossover processes. Another avenue for future research at the couple level would be to examine JI at a dyadic level in couples by profiling those couples in which both partners experience JI and also examine its effects at a dyadic level (e.g., marital role quality, family functioning within a couple/family). Dyadic research calls for multilevel research design both in data collection and statistical analysis. Naturally, the effects of mothers/fathers JI on their child(ren) could also be studied using a dyadic design.

\section{CONCLUSIONS}

\section{Concluding Remarks, Limitations and Implications for Employers}

To the best of our knowledge, this qualitative review presents the first attempt to summarize and evaluate the findings of studies on the relationships between perceived JI and family-related outcomes. This review indicates that JI is related to various family-related outcomes. Generally, the findings provide support for the three theoretical models (COR, spillover, crossover) presented in the introduction. Consistent with COR theory (Hobfoll, 1989, 2001), JI 
seems to constitute a threat of resource loss (an anticipated threat of job loss), which is likely to be associated with subsequent resource losses in terms of poorer family well-being as the endpoint of resource loss. The spillover model describes within-individual relationships of work-family interface (i.e., an employee's work experiences affect his/her own family-related well-being or performance; see Kinnunen et al., 2014; Lambert, 1990). The results showed that JI spilled over into an employee's family-related well-being directly or indirectly via mediators (e.g., workfamily conflict, perceived workload). Finally, the crossover model (Kinnunen et al., 2013; Westman et al., 2001), describing between-individual relationships of work-family interface (i.e., work experiences are transmitted from an employee to his/her family members by affecting their well-being or performance), was also supported since JI crossed over between family members, specifically from parents to children. These crossover findings in particular can be considered to be 'real family-related outcomes' because in such a crossover process an employee's JI is transmitted to his/her family members.

However, as nearly all the studies reviewed were cross-sectional we cannot draw causal inferences and in this respect the core assumptions of the theories presented above are still insufficiently examined. For example, the core tenets of the COR model can be reliably tested only in longitudinal designs, that is, whether a threat of resource losses (JI) accumulates, resulting in a spiral of losses (impaired family well-being/performance as the endpoint). Consequently, we encourage researchers to examine JI and its effects from a wider family-related perspective preferably via longitudinal designs. Moreover, indirect processes, i.e., mediators, as well as life circumstances and other factors that render an employee more vulnerable to JI, that is, moderators, also deserve attention in researching the family outcomes of JI. Mediator effects in particular call for longitudinal designs. Theoretical models developed specifically in work-family interface 
research, i.e., the spillover and crossover models, should also guide future research on familyrelated outcomes of JI. It is noteworthy that the empirical studies reviewed here have used different theoretical frameworks, yet research in this era would certainly benefit from more unified and holistic theoretical model(s).

In addition, no studies on cross-cultural comparisons concerning family outcomes of JI were found, even though it is likely that these effects differ across countries or welfare regimes, depending, e.g., on values, traditions, and social policy issues. It has recently been shown that the predictors of JI may vary across cultures (Keim, Landis, Pierce, \& Earnest, 2014) and this may also be true for the family outcomes of JI. Accordingly, cultural context may serve as a moderator between JI and family outcomes. Significantly, only a few studies in this review considered a nonwestern context and more cultural variation and cross-cultural comparisons are needed in the future.

There are some noteworthy limitations in this review. Our review does not cover all studies on the topic because we included only quantitative studies published in English in peer-reviewed journals. Furthermore, we adopted a narrative approach because we wanted to provide a rich description of the results, also including moderator and mediator associations, which could not have been analyzed via meta-analysis since there was a small number of studies overall and particularly of studies examining moderator and mediator relationships. When the number of studies increases in this field, a meta-analytic approach will be warranted. One important remark is that we focused on perceived JI and its family-related outcomes and not on structural JI (e.g., temporary work, atypical work arrangements), the results of which have recently been summarized elsewhere (Mauno, Kinnunen, Rantanen, \& Mäkikangas, 2015). Furthermore, the detrimental role of perceived JI on employees' well-being is much more consistent than the role of structural JI 
(see De Cuyper et al., 2008). This fact afforded a basis for concentrating on perceived JI and its family-related outcomes.

To sum up, this review presents preliminary evidence that JI may have a far-reaching effect on employees' families through the processes of spillover and crossover. Research has already shown that unemployment/job loss may have severe psychosocial ramifications for families (Schliebner \& Peregoy, 1994; Shupe \& Buchholz, 2013). The purpose of this review was to ascertain whether this is also true for JI, which, after all, is a less visible stressor than unemployment/job loss (Jacobson, 1991). Our findings, based on 25 empirical studies, showed that JI may indeed have 'latent costs' for employees' families, an issue which also needs to be considered in interventions and work life development.

Accordingly, our findings also have clear implications for organizations and employers. We propose that interventions which help employees to decrease or tolerate JI may have certain 'latent benefits' for their families. Various contextual resources, e.g., good organizational communication, social support, and decision latitude at work, and non-contextual resources, e.g., personal coping/recovery strategies, feelings of self-efficacy, career management skills, are helpful in the presence of JI (see more Cheng \& Chan, 2008; Keim et al., 2014; Mauno \& Kinnunen, 2002). For example, during organizational changes, which are prevalent today and which increase employees' JI, honest, open and timely communication on changes will help employees to tolerate and manage JI (Cawsey, Deszca, \& Ingols, 2016). In addition, an individual employee should ensure that (s)he is capable of detaching mentally from work while not working as good off-job recovery protects against JI (Kinnunen, Mauno, \& Siltaloppi, 2010). Such mental detachment from work may be achieved by engaging in positive family activities during off-job time. We suggest 
that these measures and resources, may prevent the adverse effects of JI from spilling over and crossing over into the family domain.

Note. ${ }^{*}$ The study is included in review (Table $1 /$ Table 2 ).

\section{References}

Barling, J. (1990). Employment, stress, and family functioning. Chichester: Wiley.

*Barling, J., Dupre, K. E., \& Hepburn, C. G. (1998). Effects of parents' job insecurity on children's work beliefs and attitudes. Journal of Applied Psychology, 83, 112-118. doi:10.1037//0021-9010.83.1.112

*Barling, J., \& Macewen, K. (1992). Linking work experiences to facets of marital functioning. Journal of Organizational Behavior, 13, 573-583. doi:10.1002/job.4030130604

*Barling, J., \& Mendelson, M. B. (1999). Parents' job insecurity affects children's grade performance through the indirect effects of beliefs in an unjust world and negative mood. Journal of Occupational Health Psychology, 4, 347-355. doi:10.1037//1076-8998.4.4.347

*Barling, J., Zacharatos, A., \& Hepburn, C. G. (1999). Parents' job insecurity affects children's academic performance through cognitive difficulties. Journal of Applied Psychology, 84, 437-444. doi:10.1037//0021-9010.84.3.437

*Batt, R., \& Valcour, P. M. (2003). Human resources practices as predictors of work-family outcomes and employee turnover. Industrial Relations, 42, 189-220. doi:10.1111/1468232x.00287

*Beham, B., \& Drobnic, S. (2009). Satisfaction with work-family balance among German office workers. Journal of Managerial psychology, 25, 669-689. doi:10.1108/02683941011056987

Cawsey, T. F., Deszca, G., \& Ingols, C. (2016). Organizational change: An action-oriented toolkit. USA: Sage.

Cheng, G. H. L., \& Chan, D. K. S. (2008). Who suffers more from job insecurity? A meta- analytic review. Applied psychology: An International Review, 57, 272-303. doi:10.1111/j.14640597.2007.00312.x

*Cheng, T., Mauno, S., \& Lee, C. (2014a). Do job control, support, and optimism help job insecure employees? A three-wave study of buffering effects on job satisfaction, vigor and workfamily enrichment. Social Indicators Research, 118, 1269-1291. doi:10.1007/s11205-0130467-8

*Cheng, T., Mauno, S., \& Lee, C. (2014b). The buffering effect of coping strategies in the relationship between job insecurity and employee well-being. Economic and Industrial Democracy, 35, 71-94. doi:10.1177/0143831x12463170

Crouter, A. C., \& McHale, S. M. (1993). Temporal rhythms in family life: Seasonal variation in the relation between parental work and family processes. Developmental Psychology, 29, 198-205. doi:10.1037//0012-1649.29.2.198

De Cuyper, N., De Jong, J., De Witte, H., Isaksson, K., Rigotti, T., \& Schalk, R. (2008). Literature review of theory and research on the psychological impact of temporary employment: 
Towards a conceptual model. International Journal of Management Reviews, 10, 25-51. doi:10.1111/j.1468-2370.2007.00221.x

Frone, M. R. (2003). Work-family balance. In J. C. Quick \& L. E. Tetrick (Eds.), Handbook of occupational health psychology (pp.143-162). Washington, DC: American Psychological Association.

Frone, M. R., Russell, M., \& Cooper, M.L. (1992). Antecedents and outcomes of work-family conflict: Testing a model of the work-family interface. Journal of Applied Psychology, 77, 65-78. doi:10.1037//0021-9010.77.1.65

Greenhaus, J. H., \& Beutell, N. J. (1985). Sources of conflict between work and family roles. Academy of Management Review, 10, 76-88. doi:10.5465/amr.1985.4277352

Greenhalgh, L., \& Rosenblatt, Z. (1984). Job insecurity: Toward conceptual clarity. Academy of Management Review, 3, 438-448. doi:10.2307/258284

Hobfoll, S. E. (1989). Conservation of resources: A new attempt at conceptualizing stress. American Psychologist, 44, 513-524. doi:10.1037//0003-066x.44.3.513

Hobfoll, S. E. (2001). The influence of culture community and the nested-self in the stress process: Advancing conservation of resources theory. Applied Psychology: An International Journal, 50, 337-421. doi:10.1111/1464-0597.00062

*Hughes, D., \& Galinsky, E. (1994). Work experiences and marital interactions: Elaborating the complexity of work. Journal of Organizational Behavior, 15, 423-438. doi:10.1002/job.4030150507

*Hughes, D., Galinsky, E., \& Morris, A. (1992). The effects of job characteristics on marital quality: Specifying linking mechanisms. Journal of Marriage and Family, 54, 31-42. doi: $10.2307 / 353273$

Jacobson, D. (1991). The conceptual approach to job insecurity. In J. Hartley, D. Jacobson, B. Klandermans, \& T. Van Vuuren (Eds.), Job insecurity. Coping with jobs at risk (pp. 2339). London: Sage.

Keim, A. C., Landis, R. S., Pierce, C. A., \& Earnest, D. R. (2014). Why do employees worry about their jobs? A meta-analytic review of predictors of job insecurity. Journal of Occupational Health Psychology, 19, 269-290. doi:10.1037/a0036743

Kinnunen, U., Mäkikangas, A., Mauno, S., De Cuyper, N., \& De Witte, H. (2014). Development of perceived job insecurity across two years: Associations with antecedents and employee outcomes. Journal of Occupational Health Psychology, 19, 243-258. doi: $10.1037 / \mathrm{a} 0035835$

*Kinnunen, U., \& Mauno, S. (1998). Antecedents and outcomes of work-family conflict among employed women and men in Finland. Human Relations, 51, 157-177. doi:10.1177/001872679805100203

Kinnunen, U., Mauno, S., \& Siltaloppi, M. (2010). Job insecurity, recovery and well-being at work: Recovery experiences as moderators. Economic and Industrial Democracy, 31, 179194. doi: $10.1177 / 0143831 \times 09358366$

Kinnunen, U., Rantanen, J., \& Mauno, S. (2013). Crossover and spillover between family members and work and family roles. In D. A. Major \& R. J. Burke (Eds.), Handbook of work-life integration among professionals: Challenges and opportunities (pp. 77-92). USA: Edward Elgar.

Kinnunen, U., Rantanen, J., Mauno, S., \& Peeters, M. (2014). Work-family interaction. In M. Peeters, J. de Jonge, \& T. W. Taris (Eds.), An introduction to contemporary work psychology (pp. 267-290). UK: John Wiley \& Sons. 
Lambert, S. J. (1990). Processes linking work and family: A critical review and research agenda. Human Relations, 43, 239-257. doi:10.1177/001872679004300303

*Larson, J. H., Wilson, S. M., \& Beley, R. (1994). The impact of job insecurity on marital and family relationship. Family Relations, 43, 138-143. doi:10.2307/585315

Levy, D. A., \& Nail, P. R. (1993). Contagion: A theoretical and empirical review and reconceptualization. Genetic, Social \& General Psychology Monographs, 119, 233-284.

*Lim, V. K. G., \& Loo, G. L. (2003). Effects of parental job insecurity and parenting behaviors on youth's self-efficacy and work attitudes. Journal of Vocational Behavior, 63, 86-98. doi:10.1016/s0001-8791(02)00020-9

*Lim, V. K. G., \& Sng, Q. S. (2006). Does parental job insecurity matter? Money anxiety, money motives, and work motivation. Journal of Applied Psychology, 91, 1078-1087. doi:10.1037/0021-9010.91.5.1078

*Mauno, S., \& Kinnunen, U. (1999a). The effects of job stressors on marital satisfaction in Finnish dual-earner couples. Journal of Organizational Behavior, 20, 879-895. doi:10.1002/(sici)1099-1379(199911)20:6<879::aid-job982>3.0.co;2-2

*Mauno, S., \& Kinnunen, U. (1999b). Job insecurity and well-being: A longitudinal study among male and female employees in Finland. Community, Work \& Family, 2, 147-171. doi:10.1080/13668809908413938

Mauno, S., \& Kinnunen, U. (2002). Perceived job insecurity among dual-earner couples: Do its antecedents vary according to gender, economic sector and the measure used? Journal of Occupational and Organizational Psychology, 75, 295-314. doi:10.1348/096317902320369721

Mauno, S., Kinnunen, U., Rantanen, J., \& Mäkikangas, A. (2015). Work-family interface in atypical work arrangements. In A. De Vos \& B. Van Der Heijden (Eds.), Handbook of Research on Sustainable Careers (pp. 239-254). UK: Edward Elgar.

Mauno, S., Leskinen, E., \& Kinnunen, U. (2001). Multi-wave, multi-variable models of job insecurity: Applying different scales in studying the stability of job insecurity. Journal of Organizational Behavior, 22, 919-937. doi:10.1002/job.122

Porfeli, E. J., Wang, C., \& Hartung, P. J. (2008). Family transmission of work affectivity and experiences to children. Journal of Vocational Behavior, 73, 278-286. doi:10.1016/j.jvb.2008.06.001

Repetti, R. L., \& Wood, J. (1997). Effects of daily stress at work on mothers' interactions with preschoolers. Journal of Family Psychology, 11, 90-108. doi:10.1037//0893-3200.11.1.90

*Richter, A., Näswall, K., \& Sverke, M. (2010). Job insecurity and its relation to work-family conflict: Mediation with a longitudinal data set. Economic and Industrial Democracy, 31, 265-280. doi:10.1177/0143831x09358370

*Roeters, A., van der Lippe, T., \& Kluwer, E. (2009). Parental work demands and the frequency of child-related routine and interactive activities. Journal of Marriage and Family, 71, 1193-1204. doi:10.1111/j.1741-3737.2009.00663.x

*Roeters, A., van der Lippe, T., \& Kluwer, E. (2010). Work characteristics and parent-child relationship quality: The mediating role of temporal involvement. Journal of Marriage and Family, 72, 1317-1328. doi:10.1111/j.1741-3737.2010.00767.x

*Ruokolainen, M., Mauno, S., \& Cheng, T. (2014). Are the most dedicated nurses more vulnerable to job insecurity? Age-specific analyses on family-related outcomes. Journal of Nursing Management, 22, 1042-1053. doi:10.1111/jonm.12064 
Schliebner, C. T., \& Peregoy, J. (1994). Unemployment effects on the family and the child: Interventions for counselors. Journal of Counseling and Development, 72, 368-372. doi:10.1002/j.1556-6676.1994.tb00951.x

Shupe, E. I., \& Buchholz, K. A. (2013). The effects of not working: A psychological framework for understanding the experience of job loss. In A.-S. Antoniou \& C. L. Cooper (Eds.), The psychology of the recession on the workplace (pp. 209-299). Northampton, MA: Edward Elgar.

*Stewart, W., \& Barling, J. (1996). Fathers' work experiences effect children's behaviors via jobrelated affect and parenting behaviors. Journal of Organizational Behavior, 17, 221-232. doi:10.1002/(sici)1099-1379(199605)17:3<221::aid-job741>3.0.co;2-g

Sverke, M., Hellgren, J., \& Näswall, K. (2002). No security: A meta-analysis and review of job insecurity and its consequences. Journal of Occupational Health Psychology, 7, 242-264. doi:10.1037//1076-8998.7.3.242

*Voydanoff, P. (2004). The effects of work demands and resources on work-to-family conflict and facilitation. Journal of Marriage and Family, 66, 398-412. doi:10.1111/j.17413737.2004.00028.x

*Voydanoff, P. (2005). Work demands and work-to-family and family-to-work conflict: Direct and indirect relationships. Journal of Family Issues, 26, 707-726. doi: $10.1177 / 0192513 \times 05277516$

Voydanoff, P. (2007). Work, family, and community: Exploring interconnections. Journal of Marriage and Family, 69, 894-896.

*Westman, M., Etzion, D., \& Danon, E. (2001). Job insecurity and crossover of burnout in married couples. Journal of Organizational Behavior, 22, 467-481. doi:10.1002/job.91

*Zhao, X., Lim, K. G. V., \& Teo, T. S. H. (2012). The long arm of job insecurity: Its impact on career-specific parenting behaviors and youths' career self-efficacy. Journal of Vocational Behavior, 80, 619-628. doi:10.1016/j.jvb.2012.01.018 
Table 1. Summary of studies examining family outcomes of JI from a spillover perspective.

\begin{tabular}{|c|c|c|c|c|c|}
\hline Authors & Sample & Country & Measures & $\begin{array}{c}\text { Stat. method } \\
\text { \& study } \\
\text { design }\end{array}$ & Main Results \\
\hline $\begin{array}{l}\text { Barling and } \\
\text { Macewen, } \\
\text { (1992) }\end{array}$ & $\begin{array}{c}190 \\
\text { employed } \\
\text { married } \\
\text { couples } \\
(110 \\
\text { women } \\
\text { and } 80 \\
\text { men). }\end{array}$ & Canada & $\begin{array}{c}\text { IVs: JI } \\
\text { (Ashford et al., } \\
\text { 1989), job } \\
\text { satisfaction, } \\
\text { role conflict, } \\
\text { role ambiguity. } \\
\text { Med: } \\
\text { Concentration } \\
\text { difficulties, } \\
\text { depression. } \\
\text { DVs: General } \\
\text { marital } \\
\text { satisfaction, } \\
\text { sexual } \\
\text { satisfaction, } \\
\text { psychological } \\
\text { aggression. }\end{array}$ & $\begin{array}{l}\text { Structural } \\
\text { equation } \\
\text { modeling } \\
\text { (path } \\
\text { analysis). } \\
\text { Cross- } \\
\text { sectional } \\
\text { design. }\end{array}$ & $\begin{array}{c}\text { The effects of } \\
\text { JI on marital } \\
\text { well-being in } \\
\text { terms of } \\
\text { general marital } \\
\text { satisfaction, } \\
\text { sexual } \\
\text { satisfaction, } \\
\text { and } \\
\text { psychological } \\
\text { aggression, } \\
\text { were mediated } \\
\text { by } \\
\text { concentration } \\
\text { difficulties and } \\
\text { depression. No } \\
\text { gender } \\
\text { differences } \\
\text { were found in }\end{array}$ \\
\hline
\end{tabular}




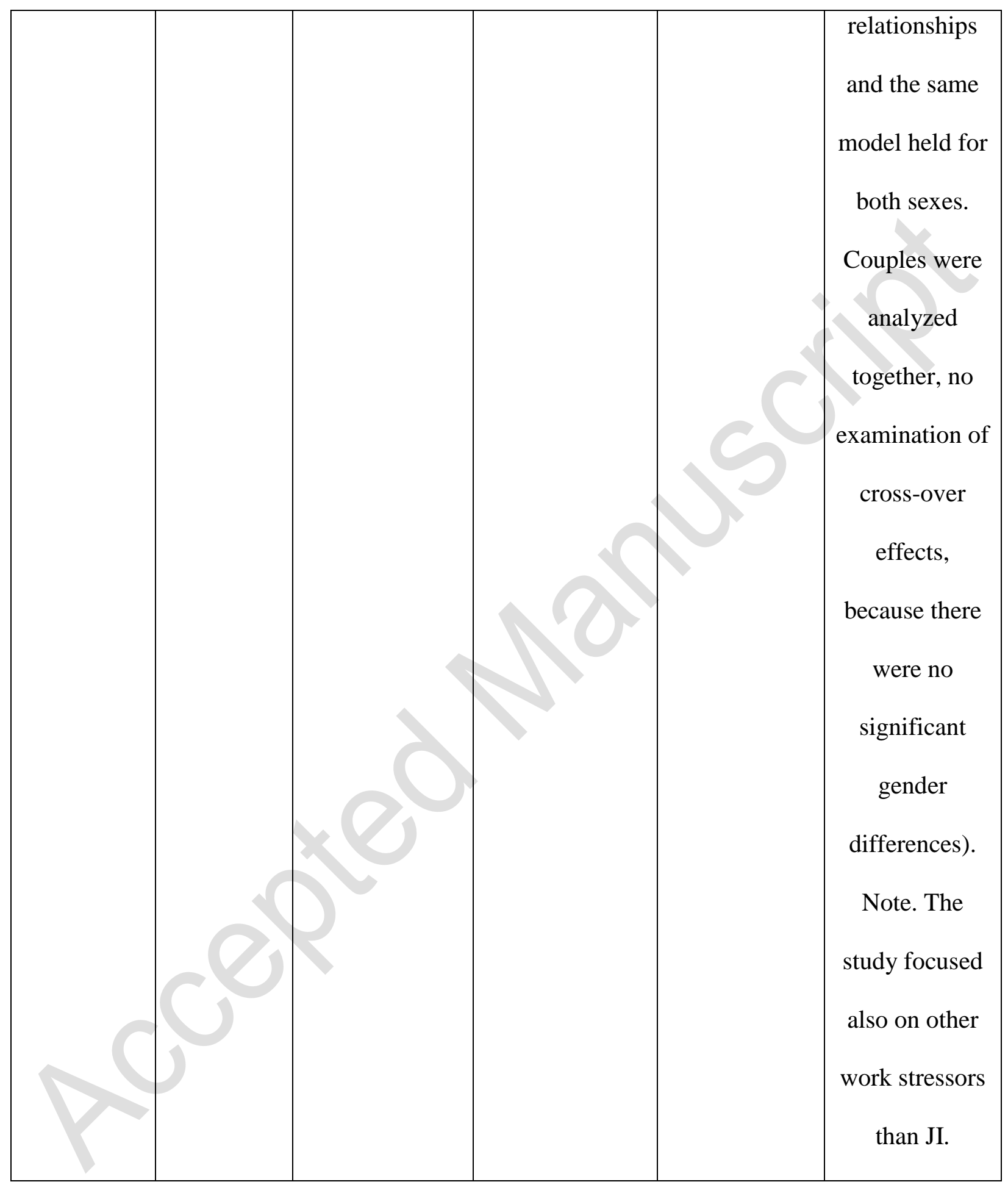




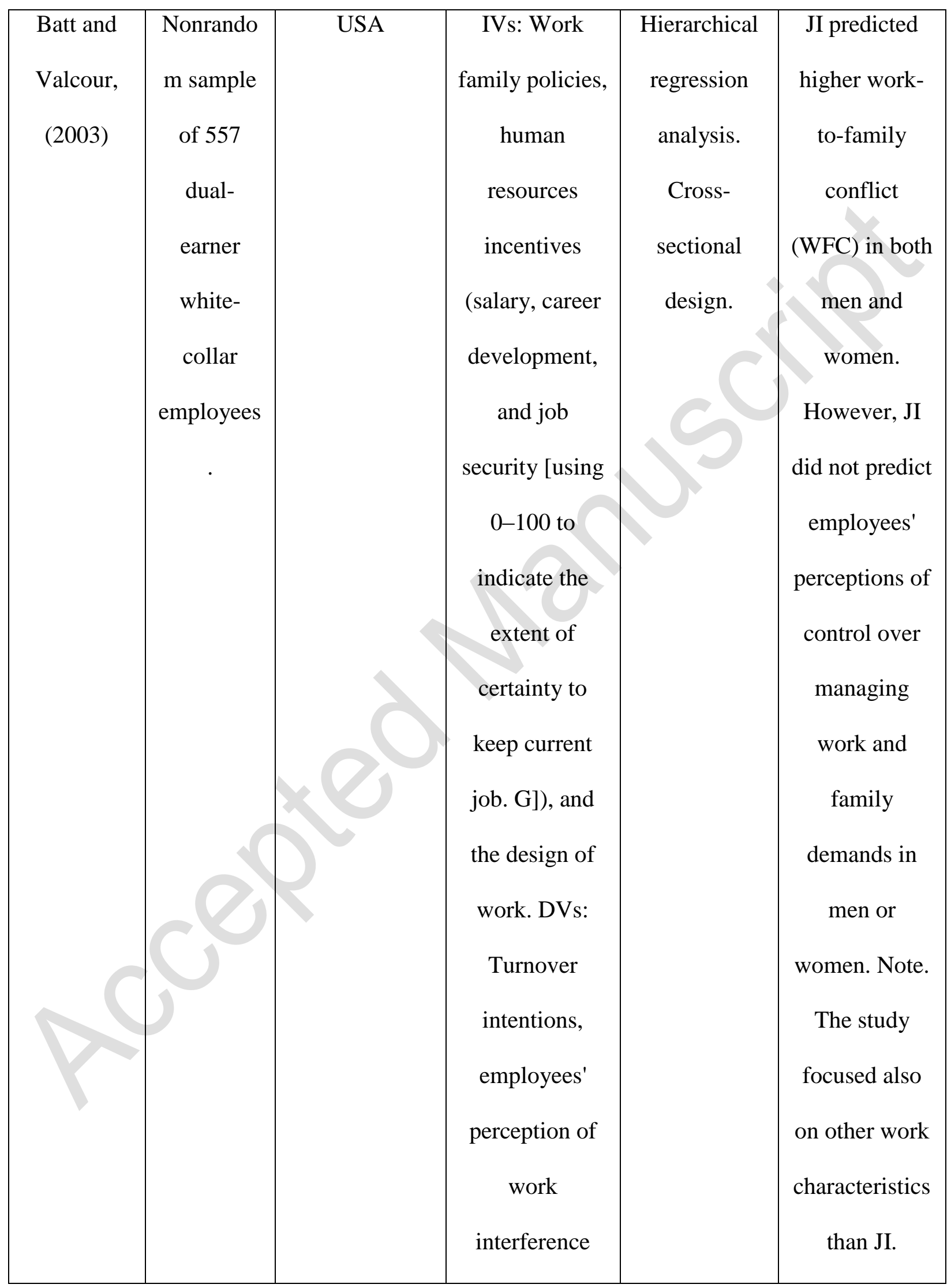




\begin{tabular}{|c|c|c|c|c|c|}
\hline & & & $\begin{array}{l}\text { with family } \\
\text { life, and their } \\
\text { control over } \\
\text { managing work } \\
\text { and family } \\
\text { demands. }\end{array}$ & & \\
\hline $\begin{array}{c}\text { Beham and } \\
\text { Drobnic } \\
\text { (2009) }\end{array}$ & $\begin{array}{l}716 \text { office } \\
\text { workers. }\end{array}$ & Germany & $\begin{array}{l}\text { IVs: Four types } \\
\text { of work } \\
\text { demands [JI } \\
\text { (Sverke et al., } \\
\text { 2004; G)], two } \\
\text { types of work } \\
\text { resources. } \\
\text { Med: Work-to- } \\
\text { family conflict } \\
\text { (measured by } \\
\text { negative work- } \\
\text { to-home } \\
\text { Satisfaction } \\
\text { with work- } \\
\text { family balance. }\end{array}$ & $\begin{array}{l}\text { Hierarchical } \\
\text { multivariate } \\
\text { regression. } \\
\text { Cross- } \\
\text { sectional } \\
\text { design. }\end{array}$ & $\begin{array}{l}\text { Low JI } \\
\text { predicted } \\
\text { employees' } \\
\text { satisfaction } \\
\text { with work- } \\
\text { family } \\
\text { balance. } \\
\text { Work-to- } \\
\text { family conflict } \\
\text { (WFC) } \\
\text { partially } \\
\text { mediated the } \\
\text { relationships } \\
\text { between JI and } \\
\text { family waction }\end{array}$ \\
\hline
\end{tabular}




\begin{tabular}{|c|c|c|c|c|c|}
\hline & & & & & $\begin{array}{c}\text { balance. First, } \\
\text { JI related to } \\
\text { higher WFC, } \\
\text { which, in turn, } \\
\text { predicted } \\
\text { lowered } \\
\text { satisfaction } \\
\text { with work- } \\
\text { family } \\
\text { balance. Note. } \\
\text { The study } \\
\text { focused also } \\
\text { on other work } \\
\text { characteristics } \\
\text { than JI. }\end{array}$ \\
\hline $\begin{array}{l}\text { Cheng et } \\
\text { al. (2013) }\end{array}$ & $\begin{array}{c}2,764 \\
\text { employees }\end{array}$ & Finland & $\begin{array}{l}\text { IVs: JI (De } \\
\text { Witte, 2000; } \\
\text { G). Mod: } \\
\text { Coping } \\
\text { strategies } \\
\text { (changing the } \\
\text { situation, } \\
\text { accommodatio }\end{array}$ & $\begin{array}{c}\text { Hierarchical } \\
\text { moderated } \\
\text { regression } \\
\text { analysis. } \\
\text { Cross- } \\
\text { sectional } \\
\text { design. }\end{array}$ & $\begin{array}{l}\text { Certain coping } \\
\text { strategies } \\
\text { moderated the } \\
\text { effects } \\
\text { between JI and } \\
\text { family-related } \\
\text { outcomes: } \\
\text { symptoms }\end{array}$ \\
\hline
\end{tabular}




\begin{tabular}{|c|c|c|c|c|c|}
\hline & & & $\begin{array}{l}\text { n, symptoms } \\
\text { reduction, } \\
\text { devaluation, } \\
\text { and avoidance). } \\
\text { DVs: Marital } \\
\text { satisfaction, } \\
\text { emotional } \\
\text { energy at } \\
\text { home, } \\
\text { emotional } \\
\text { energy at work, } \\
\text { and work } \\
\text { engagement. }\end{array}$ & 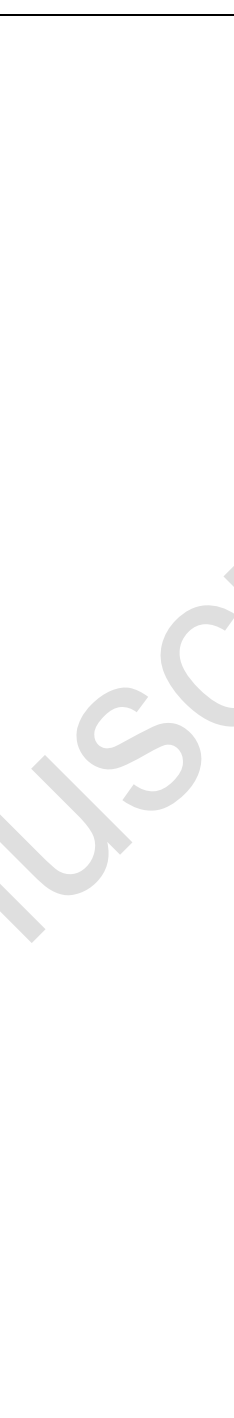 & $\begin{array}{c}\text { reduction } \\
\text { coping } \\
\text { mitigated the } \\
\text { negative effect } \\
\text { of JI on } \\
\text { emotional } \\
\text { energy at } \\
\text { home. JI } \\
\text { related directly } \\
\text { to lower } \\
\text { emotional } \\
\text { energy at } \\
\text { home and } \\
\text { lower marital } \\
\text { satisfaction. }\end{array}$ \\
\hline $\begin{array}{l}\text { Cheng et } \\
\text { al. (2013) }\end{array}$ & $\begin{array}{c}926 \\
\text { employees }\end{array}$ & Finland & $\begin{array}{l}\text { IVs: JI (De } \\
\text { Witte, 2000; } \\
\text { G). Mod: Job } \\
\text { control, social } \\
\text { support, and } \\
\text { optimism. } \\
\text { DVs: Work-to- } \\
\text { family }\end{array}$ & $\begin{array}{c}\text { Hierarchical } \\
\text { moderated } \\
\text { regression } \\
\text { analysis. } \\
\text { Three-wave } \\
\text { 2-year } \\
\text { longitudinal } \\
\text { design. }\end{array}$ & $\begin{array}{c}\text { JI at Time 1, } \\
\text { Time 2, and } \\
\text { Time } 3 \\
\text { predicted } \\
\text { lower WFE at } \\
\text { Time 1, Time } \\
\text { 2, and Time 3, } \\
\text { except that JI }\end{array}$ \\
\hline
\end{tabular}




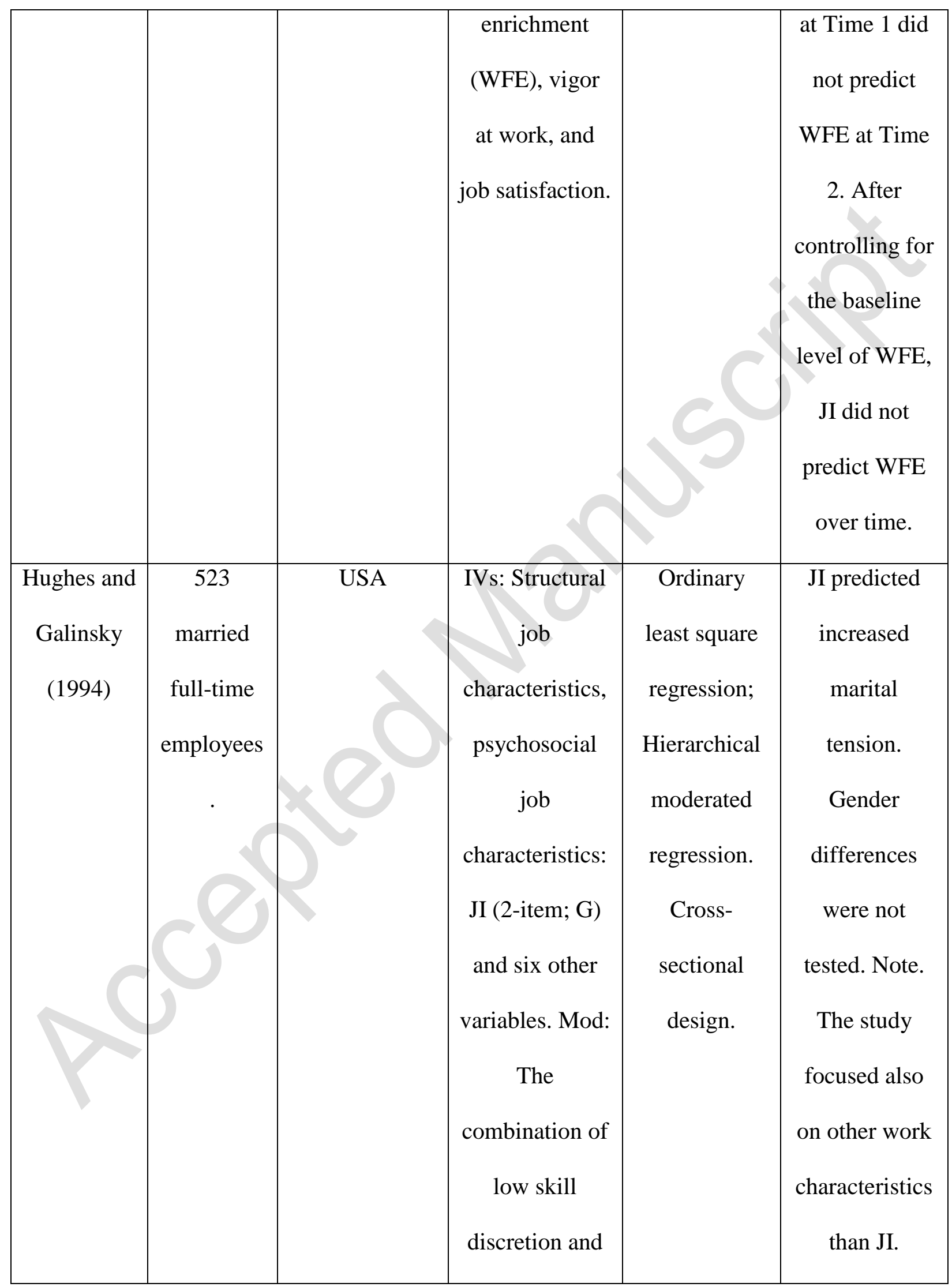




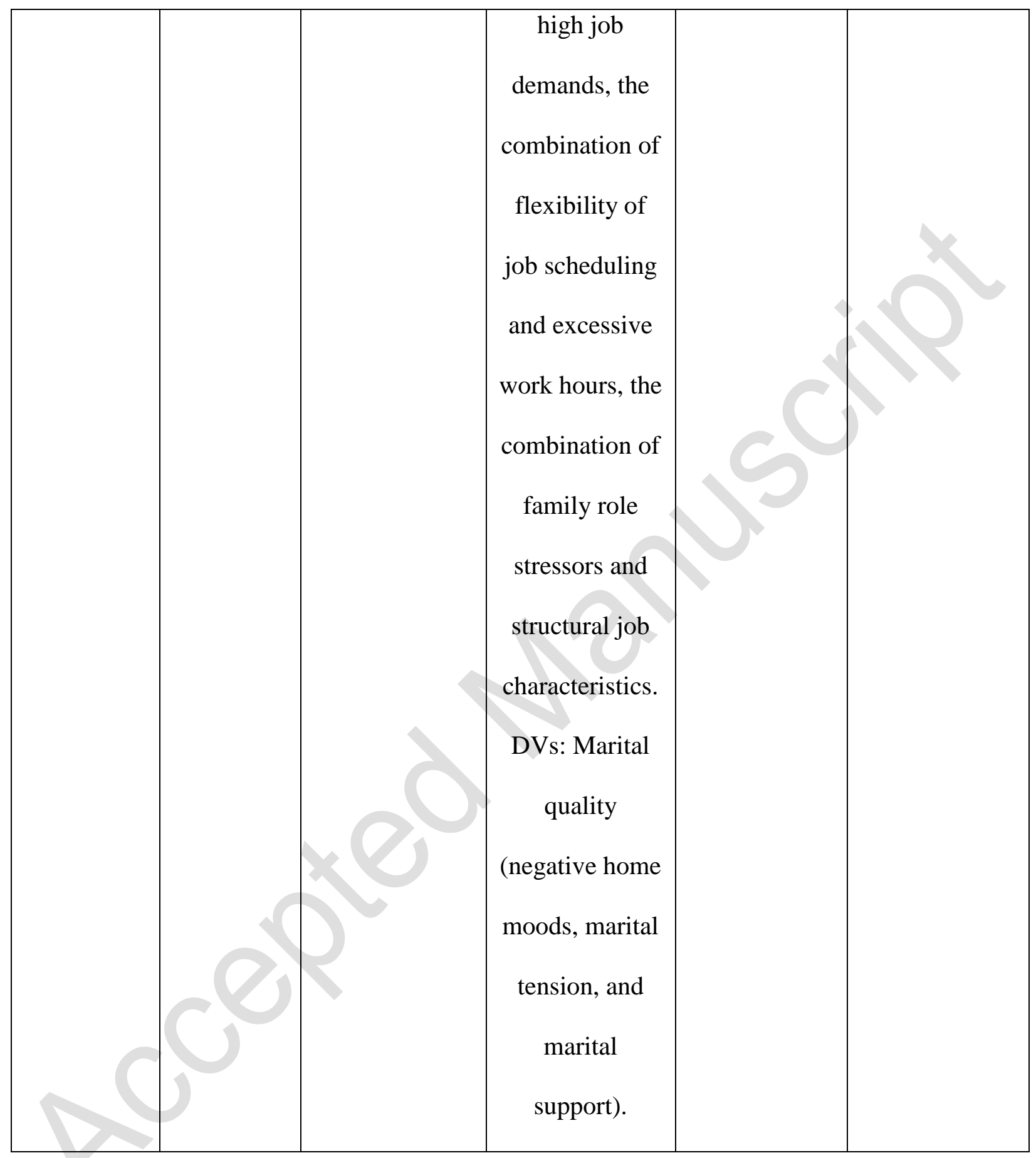




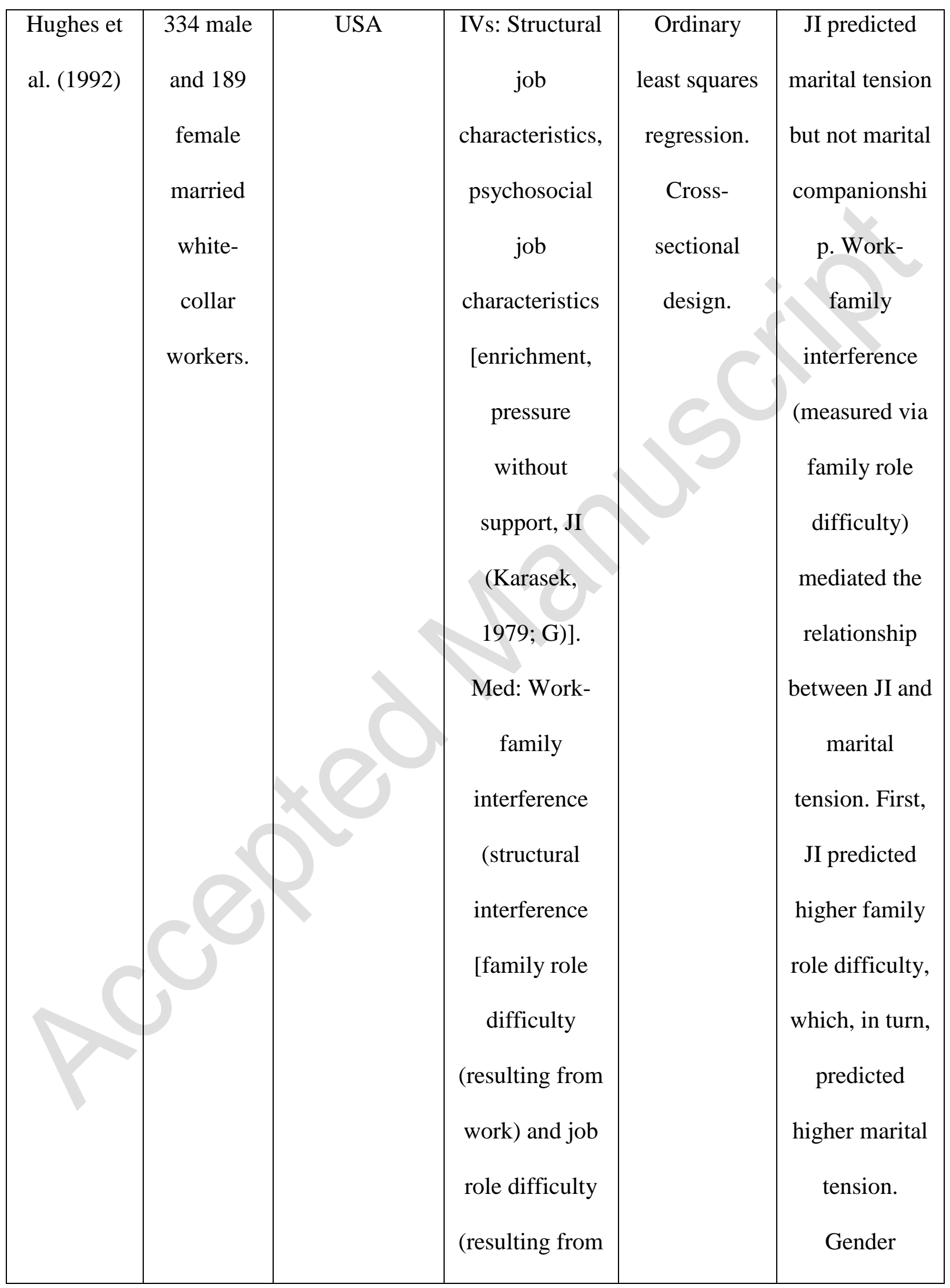




\begin{tabular}{|c|c|c|c|c|c|}
\hline & & & $\begin{array}{l}\text { family)] and } \\
\text { psychological } \\
\text { interference } \\
\text { [negative mood } \\
\text { spillover (work } \\
\text { experiences } \\
\text { resulting in } \\
\text { negative mood } \\
\text { at home)]). } \\
\text { DVs: Marital } \\
\text { quality (marital } \\
\text { tension and } \\
\text { marital } \\
\text { companionship } \\
\text { ). }\end{array}$ & & $\begin{array}{l}\text { differences } \\
\text { were not } \\
\text { tested. Note. } \\
\text { The study } \\
\text { focused also } \\
\text { on other work } \\
\text { characteristics } \\
\text { than JI. }\end{array}$ \\
\hline $\begin{array}{c}\text { Kinnunen } \\
\text { and Mauno } \\
1998\end{array}$ & $\begin{array}{c}501 \\
\text { employees } \\
\text {. }\end{array}$ & Finland & $\begin{array}{l}\text { IVs: Work } \\
\text { domain } \\
\text { antecedents for } \\
\text { work-to-family } \\
\text { conflict } \\
\text { (WFC): JI } \\
\text { (assessing the } \\
\text { concern and the }\end{array}$ & $\begin{array}{l}\text { Hierarchical } \\
\text { multiple } \\
\text { regression } \\
\text { analysis and } \\
\text { MANOVA } \\
\text { (male and } \\
\text { female } \\
\text { comparison). }\end{array}$ & $\begin{array}{l}\text { JI predicted } \\
\text { lower work-to- } \\
\text { family conflict } \\
\text { (WFC) only } \\
\text { among } \\
\text { women. JI } \\
\text { predicted } \\
\text { higher family- }\end{array}$ \\
\hline
\end{tabular}




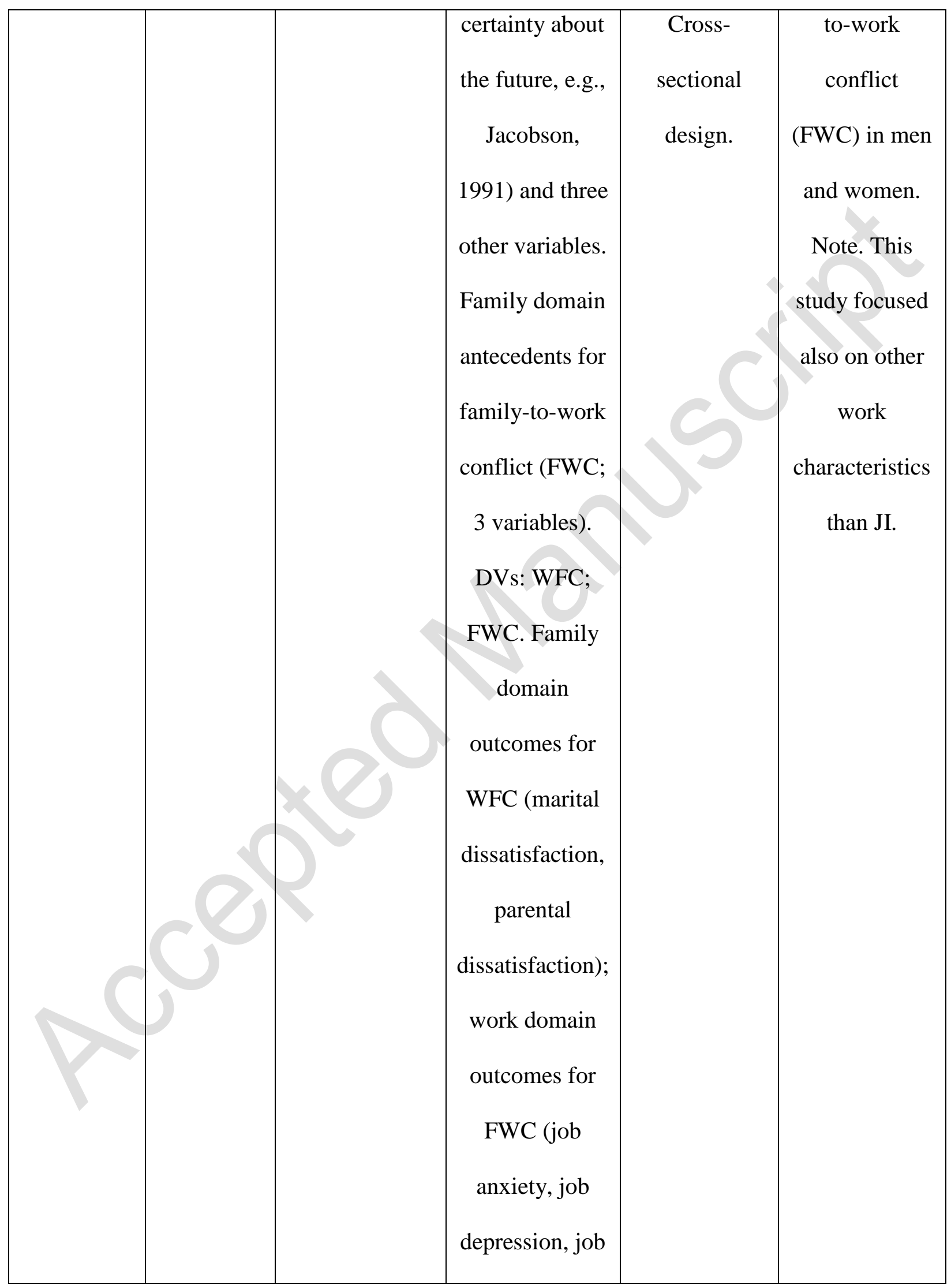




\begin{tabular}{|c|c|c|c|c|c|}
\hline & & & $\begin{array}{l}\text { exhaustion); } \\
\text { Overall well- } \\
\text { being outcomes } \\
\text { for both WFC } \\
\text { and FWC } \\
\text { (psychosomatic } \\
\text { symptoms). }\end{array}$ & & \\
\hline $\begin{array}{l}\text { Larson et } \\
\text { al. (1994) }\end{array}$ & $\begin{array}{c}111 \\
\text { couples (N } \\
=222 \text { ). } \\
\text { Within the } \\
\text { couple, at } \\
\text { least one } \\
\text { of them } \\
\text { experience } \\
\text { d JI } \\
\text { stressor. }\end{array}$ & USA & $\begin{array}{l}\text { IVs: JI (by } \\
\text { measuring } \\
\text { Unpredictabilit } \\
\text { y, Cohen, } \\
\text { Kamarck, \& } \\
\text { Marmelstein, } \\
\text { 1983; G). DVs: } \\
\text { Lower marital } \\
\text { adjustment, } \\
\text { overall family } \\
\text { functioning } \\
\text { (FAD: poorer } \\
\text { overall family } \\
\text { functioning, } \\
\text { poorer family } \\
\text { communication }\end{array}$ & $\begin{array}{l}\text { Stepwise } \\
\text { multiple } \\
\text { regression. } \\
\text { Cross- } \\
\text { sectional } \\
\text { design. }\end{array}$ & $\begin{array}{c}\text { For husbands, } \\
\text { JI predicted } \\
\text { lower marital } \\
\text { adjustment, } \\
\text { poorer overall } \\
\text { family } \\
\text { functioning, } \\
\text { lower family } \\
\text { role clarity, } \\
\text { lower family } \\
\text { affective } \\
\text { responsiveness } \\
\text {, and higher } \\
\text { marital and } \\
\text { family } \\
\text { problems. }\end{array}$ \\
\hline
\end{tabular}




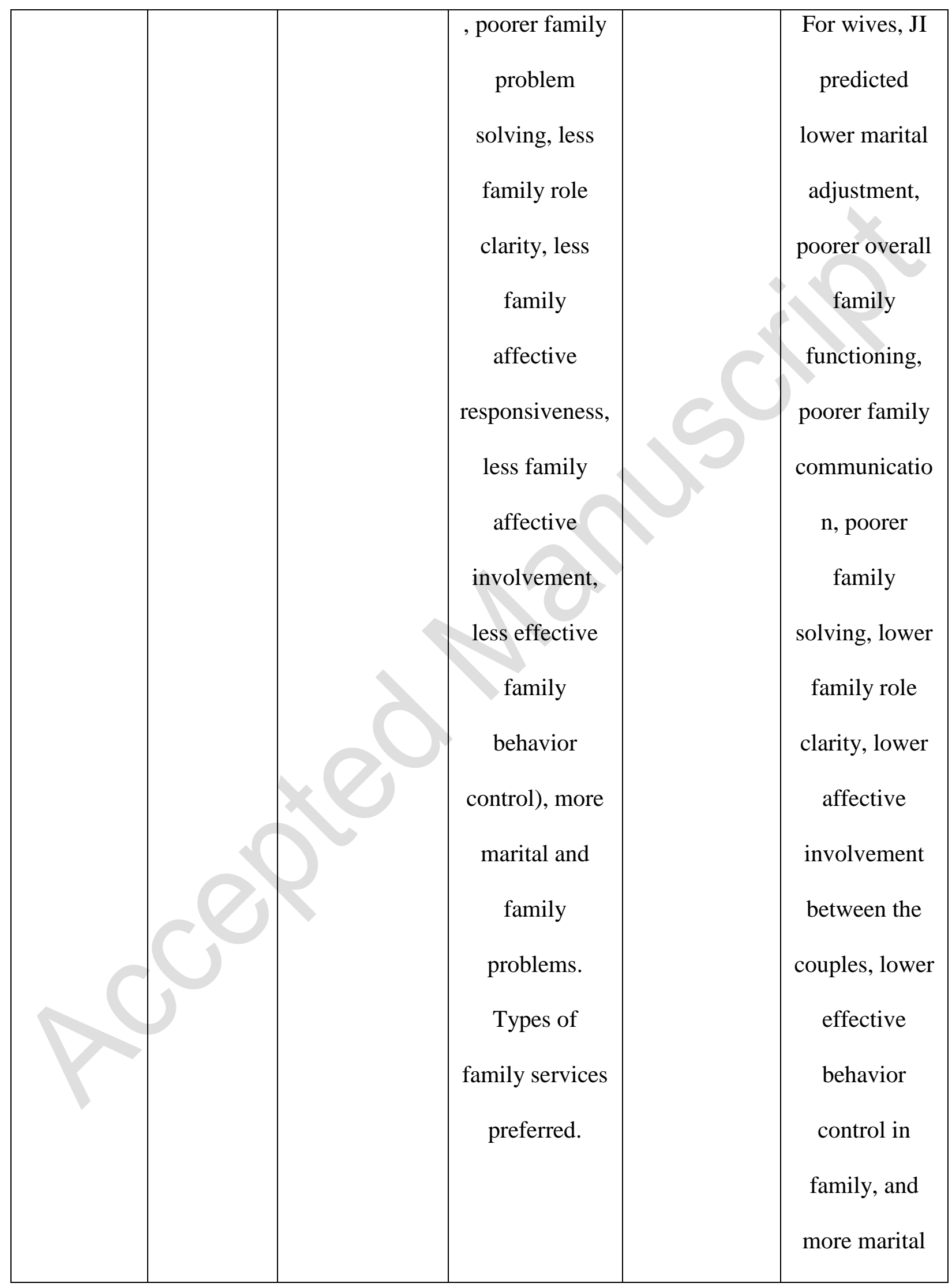




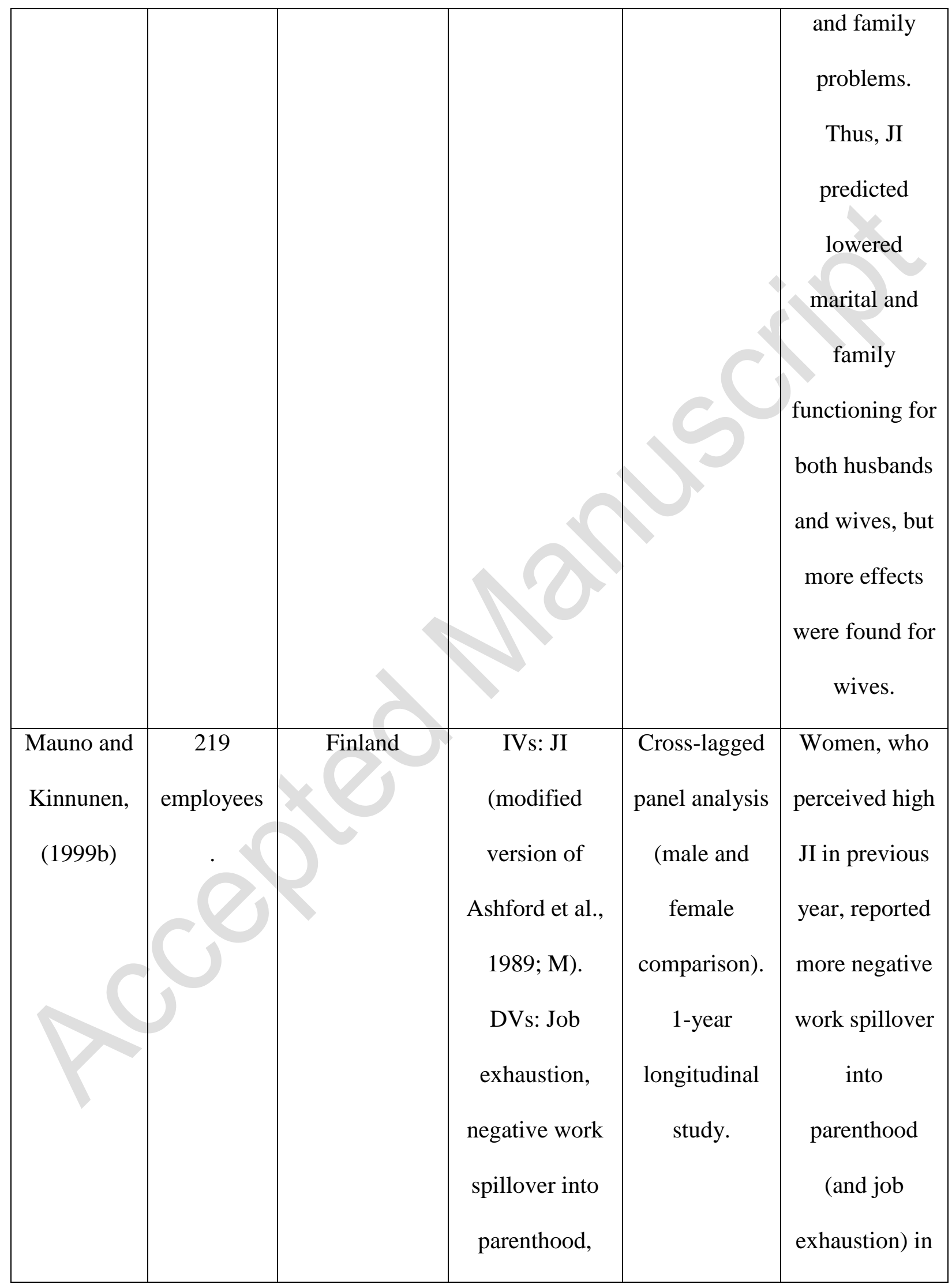




\begin{tabular}{|c|c|c|c|c|c|}
\hline & & & $\begin{array}{c}\text { somatic } \\
\text { symptoms. }\end{array}$ & & $\begin{array}{l}\text { the subsequent } \\
\text { year. JI did not } \\
\text { relate to } \\
\text { spillover } \\
\text { experiences or } \\
\text { well-being in } \\
\text { men over a } \\
\text { one-year } \\
\text { period. JI } \\
\text { operated as a } \\
\text { long-lasting } \\
\text { job stressor for } \\
\text { the female } \\
\text { employees } \\
\text { only. }\end{array}$ \\
\hline $\begin{array}{l}\text { Richter et } \\
\text { al. (2010) }\end{array}$ & $\begin{array}{c}316 \\
\text { Swedish } \\
\text { teachers. }\end{array}$ & Sweden & $\begin{array}{c}\text { IVs: JI } \\
\text { (Hellgren et al., } \\
\text { 1999; G). Med: } \\
\text { Workload. } \\
\text { DVs: Work-to- } \\
\text { family conflict. }\end{array}$ & $\begin{array}{c}\text { Robust } \\
\text { maximum- } \\
\text { likelihood } \\
\text { estimation } \\
\text { method in } \\
\text { LISREL. 1- } \\
\text { year }\end{array}$ & $\begin{array}{c}\text { Workload } \\
\text { mediated the } \\
\text { negative } \\
\text { effects } \\
\text { between JI and } \\
\text { work-to- } \\
\text { family conflict } \\
\text { (WFC) in men }\end{array}$ \\
\hline
\end{tabular}




\begin{tabular}{|c|c|c|c|c|c|}
\hline & & & longitudinal & but not in \\
women. First, \\
study. \\
JI predicted \\
higher
\end{tabular}




\begin{tabular}{|c|c|c|c|c|c|}
\hline & & & $\begin{array}{l}\text { interactive } \\
\text { activities. }\end{array}$ & & $\begin{array}{c}\text { interactive } \\
\text { activities, nor } \\
\text { mothers' } \\
\text { involvement in } \\
\text { child-related } \\
\text { routine or } \\
\text { interactive } \\
\text { activities. } \\
\text { Thus, family } \\
\text { effects were } \\
\text { found only for } \\
\text { fathers. Note. } \\
\text { The study } \\
\text { focused also } \\
\text { on other work } \\
\text { characteristics } \\
\text { than JI. }\end{array}$ \\
\hline $\begin{array}{l}\text { Roeters et } \\
\text { al. (2010) }\end{array}$ & $\begin{array}{l}1,008 \\
\text { Dutch } \\
\text { fathers and } \\
929 \text { Dutch } \\
\text { mothers } \\
\text { with }\end{array}$ & $\begin{array}{c}\text { The } \\
\text { Netherlands }\end{array}$ & $\begin{array}{l}\text { IVs: Four types } \\
\text { of work } \\
\text { stressors (for } \\
\text { instance: JI, } \\
\text { Crompton, } \\
\text { Lewis, \& }\end{array}$ & $\begin{array}{l}\text { Structural } \\
\text { equation } \\
\text { modeling. } \\
\text { Cross- } \\
\text { sectional } \\
\text { design. }\end{array}$ & $\begin{array}{c}\text { The } \\
\text { relationship } \\
\text { between } \\
\text { parental JI and } \\
\text { the nature of } \\
\text { joint time in }\end{array}$ \\
\hline
\end{tabular}




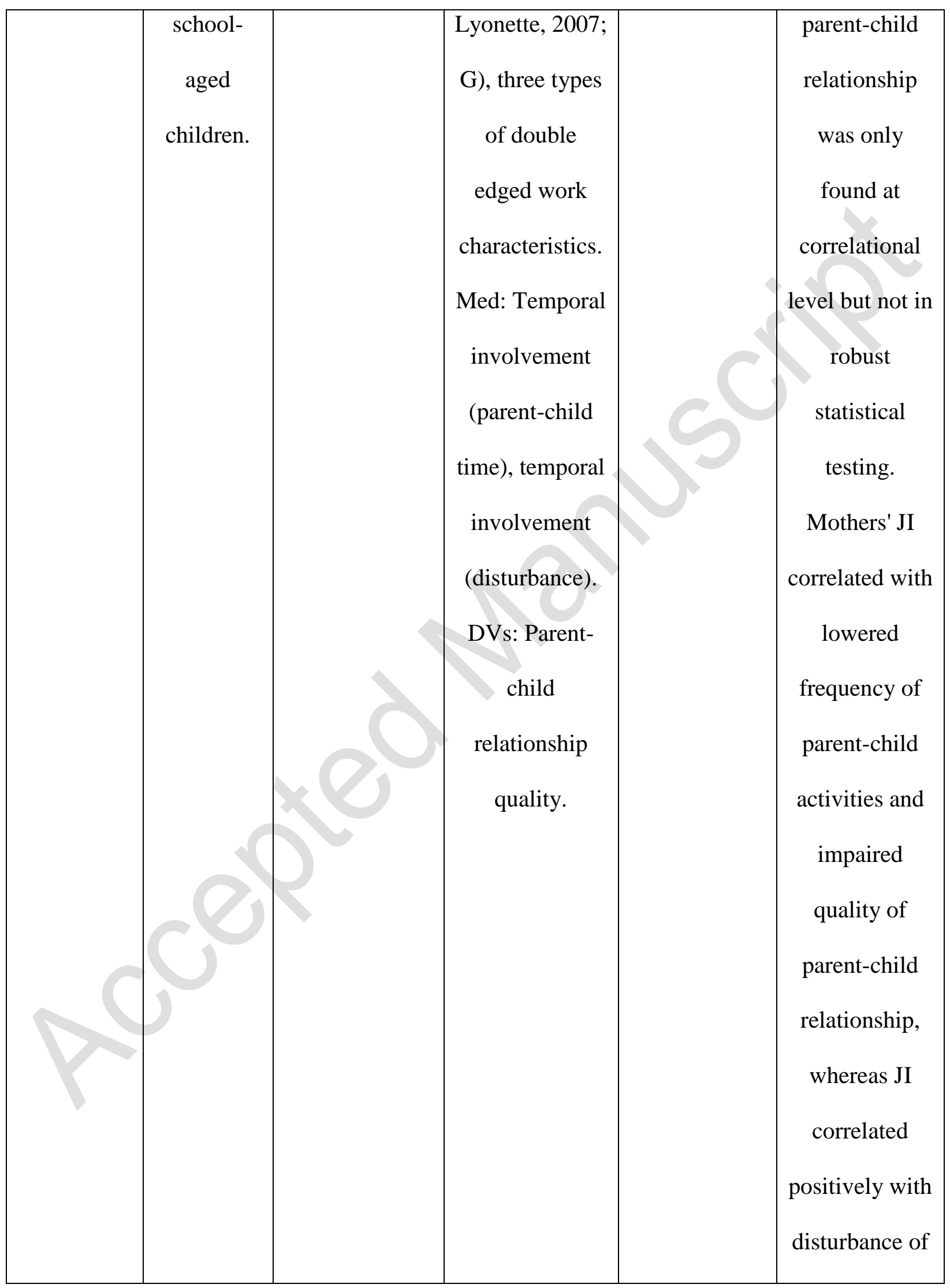




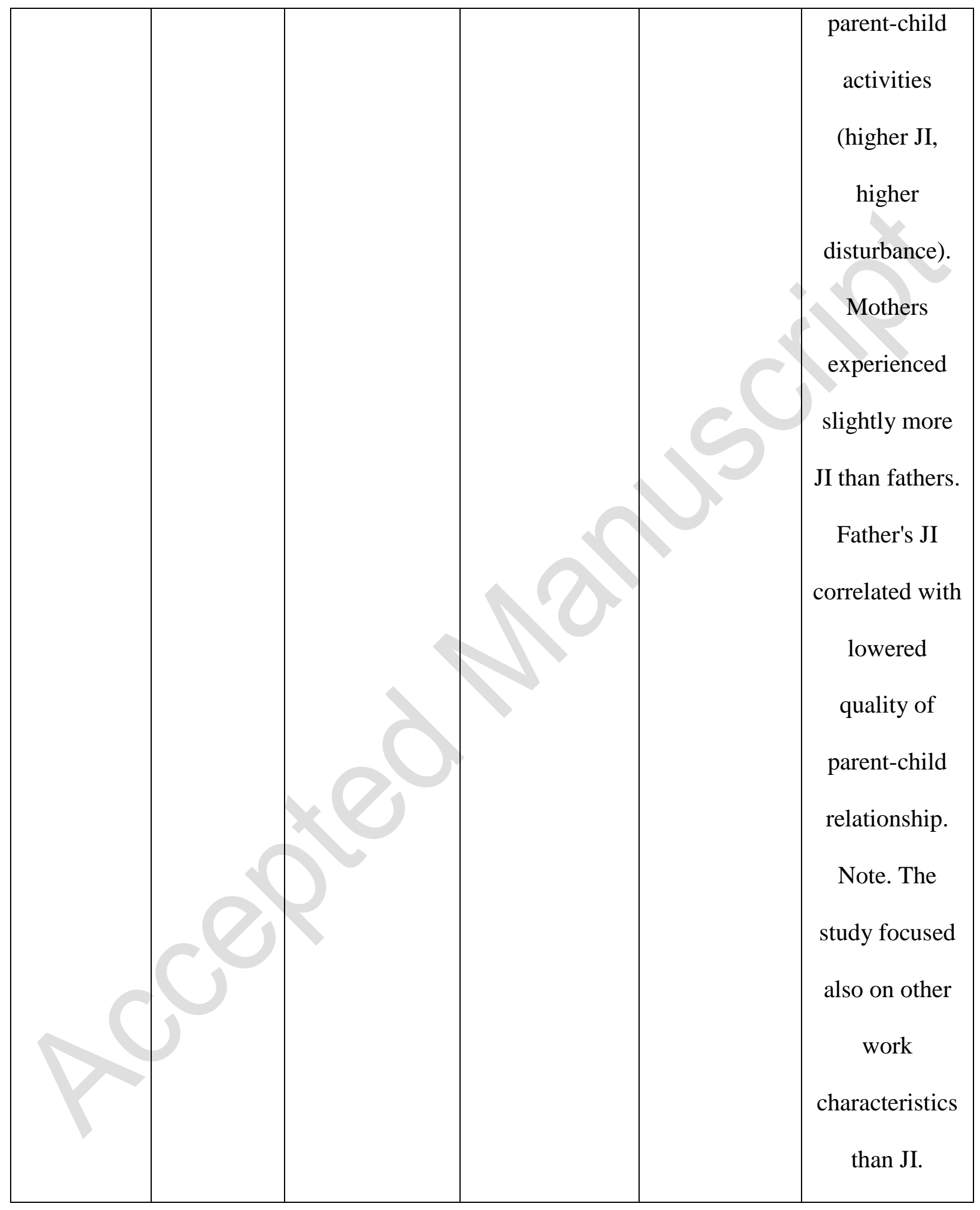




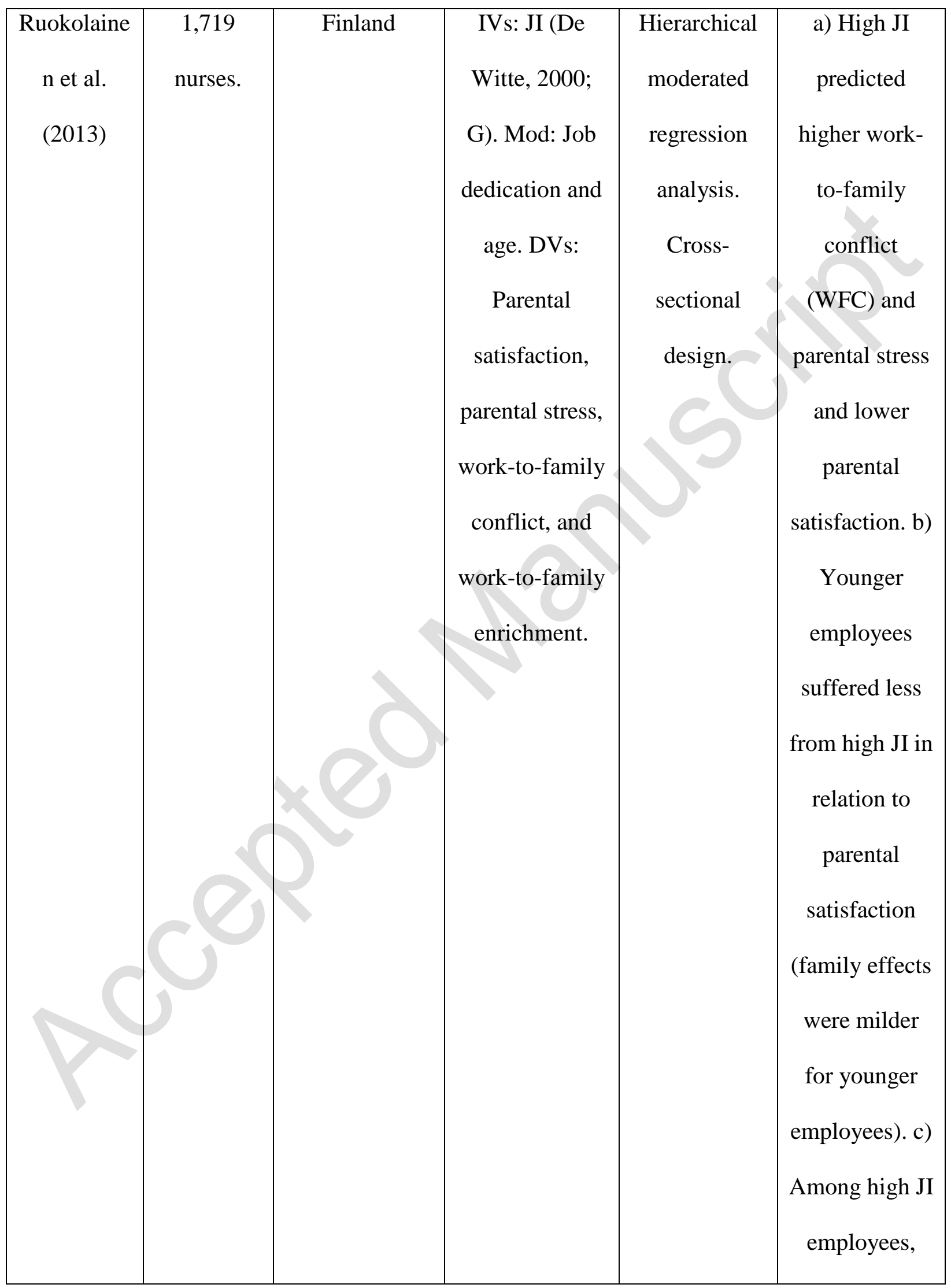




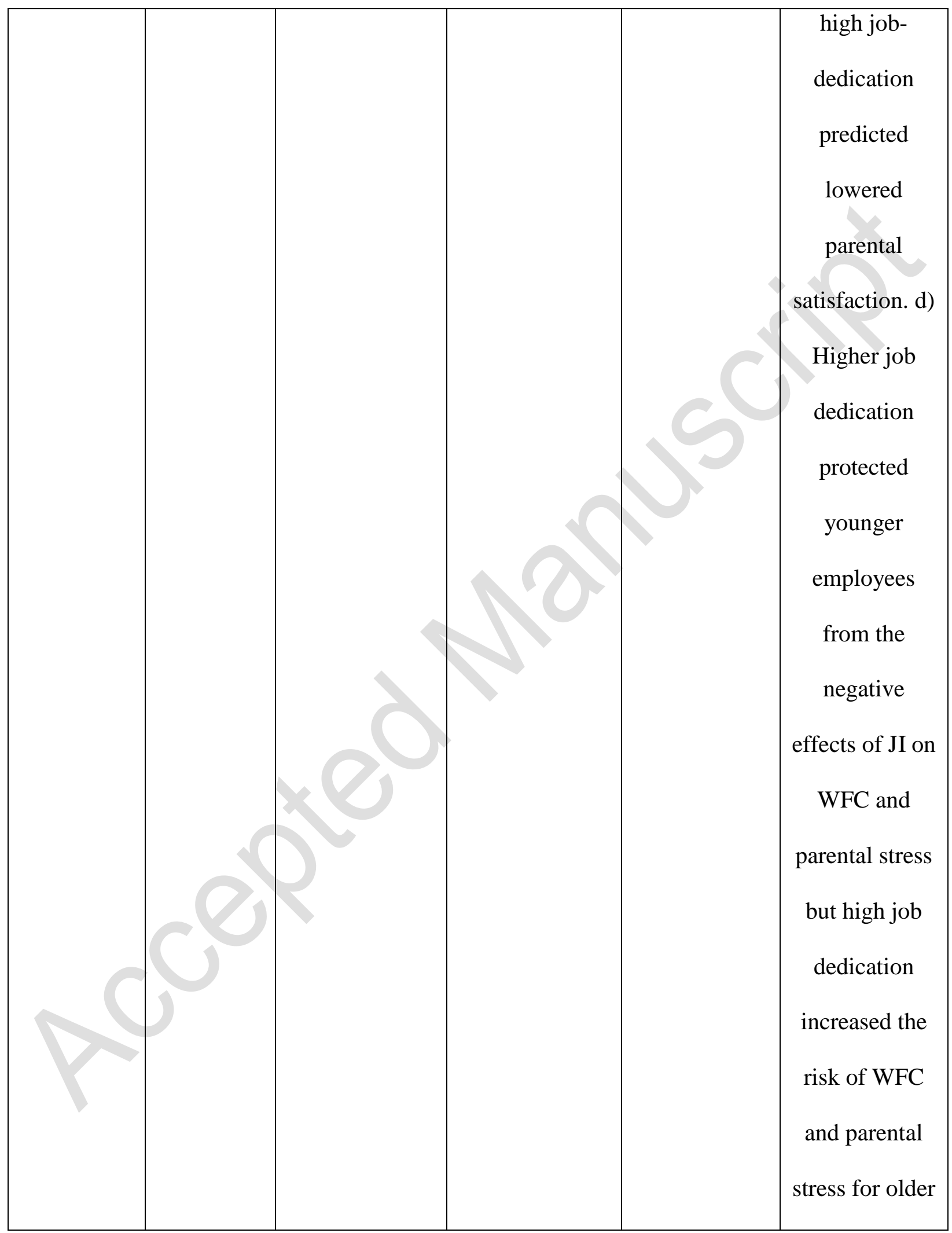




\begin{tabular}{|c|c|c|c|c|c|}
\hline & & & & & $\begin{array}{c}\text { employees } \\
\text { with high JI. }\end{array}$ \\
\hline $\begin{array}{l}\text { Voydanoff } \\
\text { (2004) }\end{array}$ & $\begin{array}{c}\text { 1,938 } \\
\text { employed } \\
\text { adults. }\end{array}$ & USA & $\begin{array}{l}\text { IVs: (1) With- } \\
\text { domain } \\
\text { demands: JI } \\
\text { (by asking how } \\
\text { likely you will } \\
\text { lose current job } \\
\text { in the next } \\
\text { couple of } \\
\text { years; G), three } \\
\text { other demands; } \\
\text { (2) Within- } \\
\text { domain } \\
\text { resources. } \\
\text { DVs: Work-to- } \\
\text { resources; (3) } \\
\text { family conflict, }\end{array}$ & $\begin{array}{l}\text { Ordinary } \\
\text { least squares } \\
\text { regression } \\
\text { analysis. } \\
\text { Cross- } \\
\text { sectional } \\
\text { design. }\end{array}$ & $\begin{array}{l}\text { JI predicted } \\
\text { higher work- } \\
\text { to-family } \\
\text { conflict } \\
\text { (WFC) and } \\
\text { lower work-to- } \\
\text { family } \\
\text { facilitation } \\
\text { (describing } \\
\text { positive work- } \\
\text { family } \\
\text { interface). } \\
\text { After } \\
\text { opportunities, } \\
\text { (autroducing }\end{array}$ \\
\hline
\end{tabular}




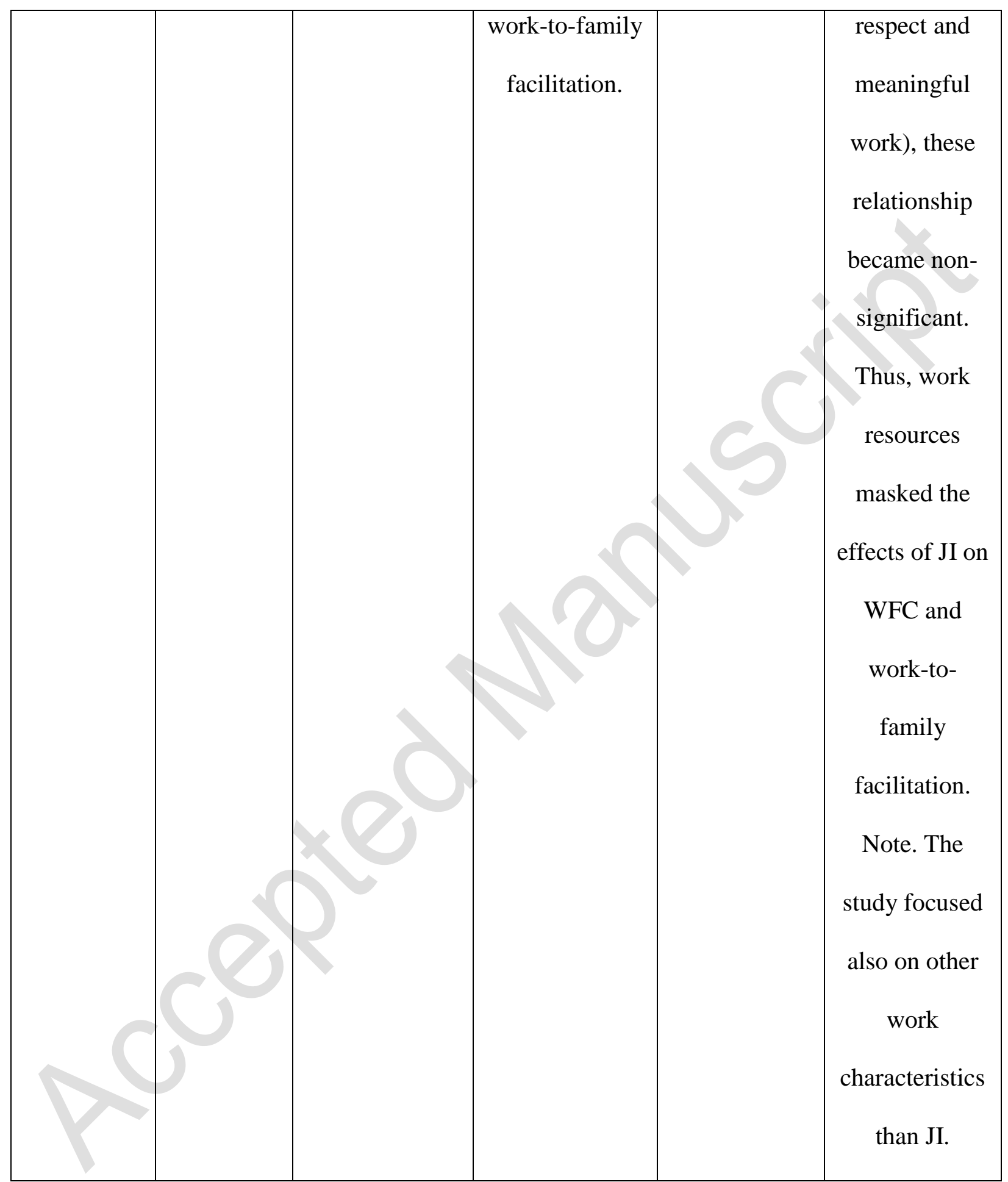




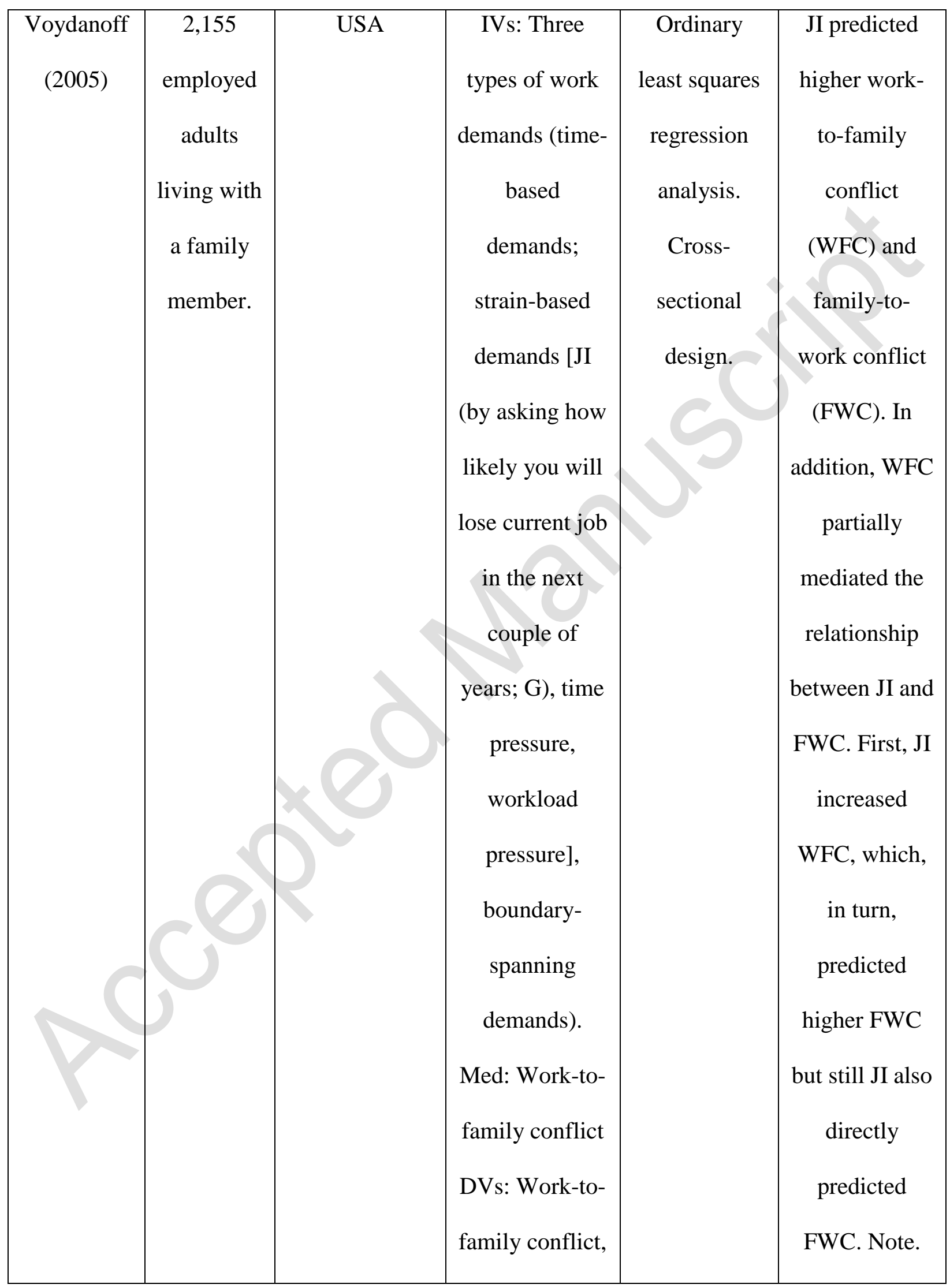




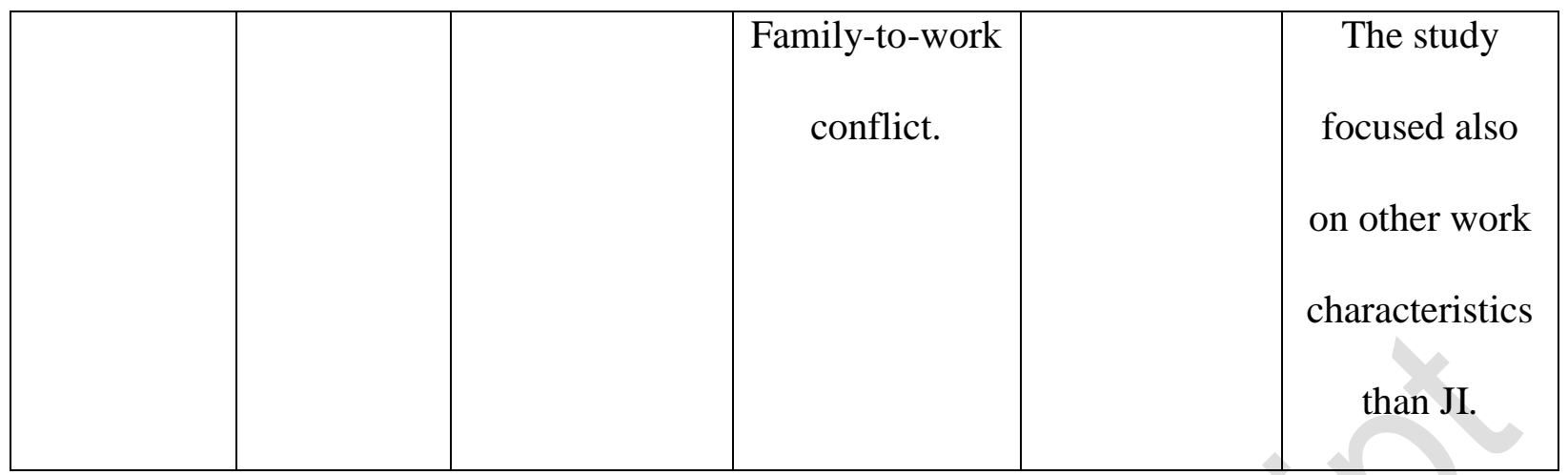

Note for abbreviation: JI = Job insecurity; G = Global measure of JI; M = Multidimensional measure of JI; IVs = Independent variables; Mod $=$ Moderators; Med $=$ Mediators; DVs $=$ Dependent variables; Stat. Method $=$ Statistical Methods. 
Table 2. Summary of studies examining family outcomes of JI from a crossover perspective.

\begin{tabular}{|c|c|c|c|c|c|}
\hline Authors & Sample & Country & Measures & $\begin{array}{c}\text { Stat. } \\
\text { method \& } \\
\text { study } \\
\text { design }\end{array}$ & Main Results \\
\hline $\begin{array}{l}\text { Barling et } \\
\text { al. (1998) }\end{array}$ & $\begin{array}{l}134 \text { undergraduate } \\
\text { students and their } \\
\text { mothers and fathers. }\end{array}$ & Canada & $\begin{array}{l}\text { IVs: Father's } \\
\text { or mother's JI } \\
\text { (Kuhnert \& } \\
\text { Vance, 1992; } \\
\text { M), father's or } \\
\text { mother's } \\
\text { layoffs. Mod: } \\
\text { Identification } \\
\text { with fathers or } \\
\text { mothers. Med: } \\
\text { Children's } \\
\text { perceptions of } \\
\text { their parents' } \\
\text { JI (revised } \\
\text { version of } \\
\text { Kuhnert \& } \\
\text { Vance, 1992; } \\
\text { M). DVs: }\end{array}$ & $\begin{array}{l}\text { Structural } \\
\text { equation } \\
\text { modeling. } \\
\text { Cross- } \\
\text { sectional } \\
\text { design. }\end{array}$ & $\begin{array}{l}\text { Fathers: } \\
\text { Fathers' JI } \\
\text { predicted } \\
\text { children's } \\
\text { perceptions of } \\
\text { their fathers' } \\
\text { JI. Children's } \\
\text { perceptions of } \\
\text { their fathers' } \\
\text { JI predicted } \\
\text { children's } \\
\text { work beliefs } \\
\text { and children's } \\
\text { work beliefs } \\
\text { predicted their } \\
\text { work } \\
\text { attitudes. } \\
\text { Mothers: }\end{array}$ \\
\hline
\end{tabular}




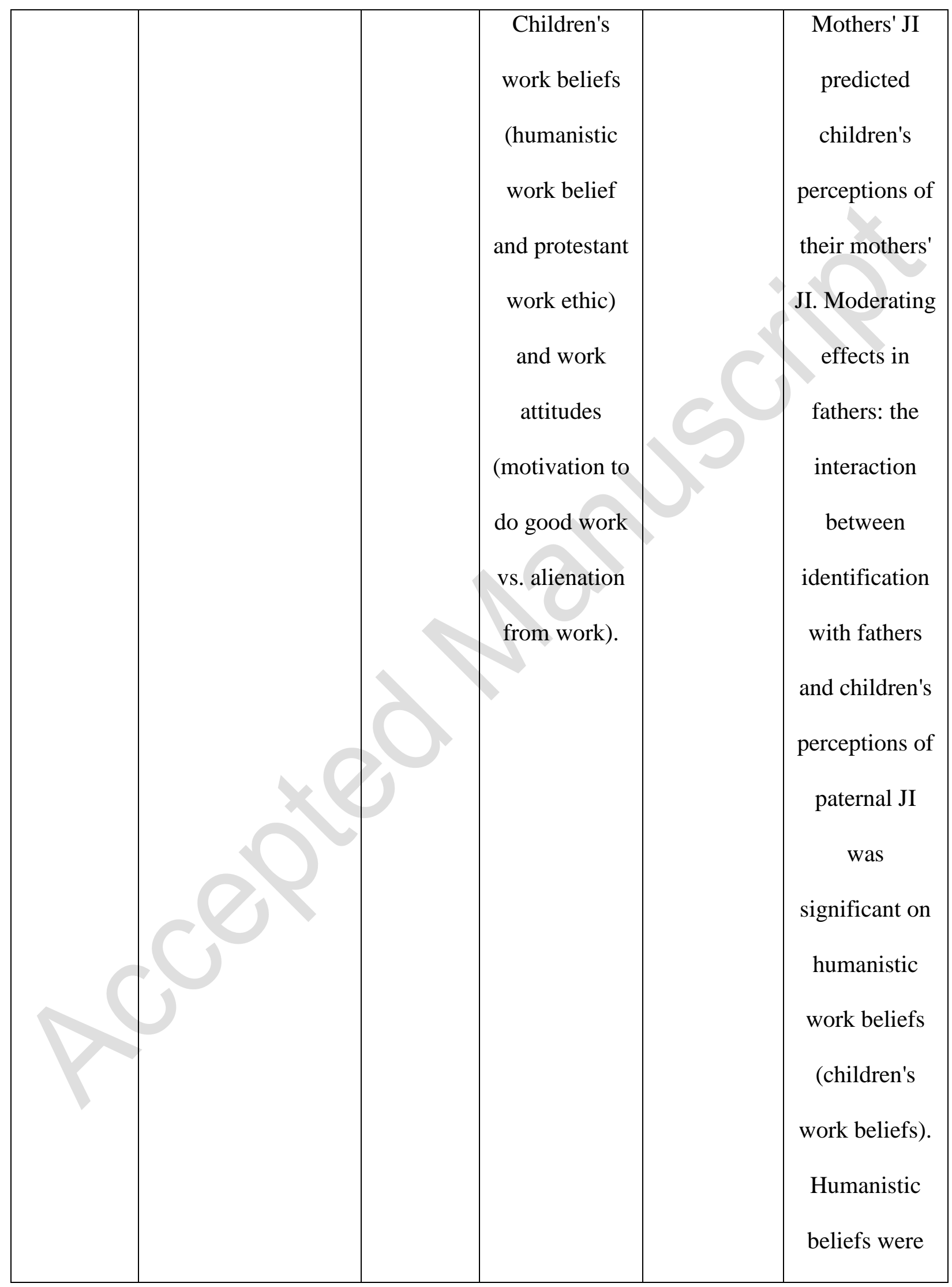




\begin{tabular}{|c|c|c|c|c|c|}
\hline & & & & & $\begin{array}{l}\text { strongly and } \\
\text { negatively } \\
\text { related to the } \\
\text { perceptions of } \\
\text { fathers' JI } \\
\text { when } \\
\text { identification } \\
\text { with the father } \\
\text { was high. } \\
\text { (Note. The } \\
\text { study focused } \\
\text { also on other } \\
\text { work stressors } \\
\text { than JI). }\end{array}$ \\
\hline $\begin{array}{l}\text { Barling } \\
\text { and } \\
\text { Mendelso } \\
\text { n (1999) }\end{array}$ & $\begin{array}{l}127 \text { undergraduate } \\
\text { students; their } \\
\text { parents } \\
\text { (father/mother/both) }\end{array}$ & Canada & $\begin{array}{l}\text { IVs: Parents' } \\
\text { self-reported } \\
\text { JI (Kuhnert \& } \\
\text { Vance, 1992; } \\
\text { M), children's } \\
\text { perceptions of } \\
\text { each parent's } \\
\text { (one or both } \\
\text { parents) JI }\end{array}$ & $\begin{array}{l}\text { Structural } \\
\text { equation } \\
\text { modeling. } \\
\text { 3-month } \\
\text { longitudinal } \\
\text { design. }\end{array}$ & $\begin{array}{l}\text { Parents' JI } \\
\text { predicted } \\
\text { children's } \\
\text { perceptions of } \\
\text { their parents' } \\
\text { JI. Children's } \\
\text { perceptions of } \\
\text { their parents' } \\
\text { JI also }\end{array}$ \\
\hline
\end{tabular}




\begin{tabular}{|c|c|c|c|c|c|}
\hline & & & $\begin{array}{l}\text { (Kuhnert \& } \\
\text { Vance, 1992; } \\
\text { M). Med: } \\
\text { Beliefs in an } \\
\text { unjust world } \\
\text { and negative } \\
\text { mood. DVs: } \\
\text { Grade } \\
\text { performance } \\
\text { (reported } 3 \\
\text { months later). }\end{array}$ & 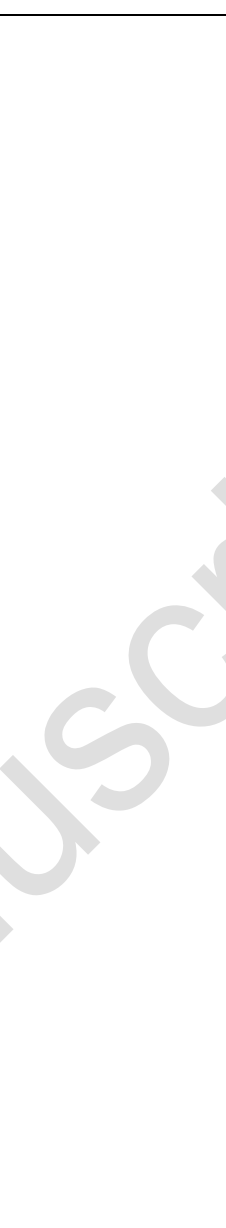 & $\begin{array}{l}\text { predicted their } \\
\text { belief in an } \\
\text { unjust world, } \\
\text { which in turn, } \\
\text { predicted } \\
\text { negative } \\
\text { mood. } \\
\text { Children's } \\
\text { negative mood } \\
\text { was associated } \\
\text { with poorer } \\
\text { school (grade) } \\
\text { performance. }\end{array}$ \\
\hline $\begin{array}{l}\text { Barling et } \\
\text { al. (1999) }\end{array}$ & $\begin{array}{l}120 \text { undergraduate } \\
\text { students, and their } \\
\text { fathers and mothers. }\end{array}$ & Canada & $\begin{array}{l}\text { IVs: Fathers' } \\
\text { and mothers' } \\
\text { reported JI } \\
\text { (Kuhnert \& } \\
\text { Vance, 1992; } \\
\text { M), children's } \\
\text { perception of } \\
\text { parental JI } \\
\text { (revised } \\
\text { version of }\end{array}$ & $\begin{array}{l}\text { Structural } \\
\text { equation } \\
\text { modeling. } \\
\text { 3-month } \\
\text { longitudinal } \\
\text { design. }\end{array}$ & $\begin{array}{c}\text { Fathers: } \\
\text { Fathers' JI } \\
\text { predicted } \\
\text { children's } \\
\text { perceptions of } \\
\text { paternal JI. } \\
\text { Children's } \\
\text { perception of } \\
\text { paternal JI } \\
\text { predicted their }\end{array}$ \\
\hline
\end{tabular}




\begin{tabular}{|l|c|c|c|c|}
\hline & Kuhnert \& \\
Vance, 1992). \\
Mod: \\
Children's \\
identification \\
with their \\
mothers and \\
fathers. Med: \\
Cognitive \\
difficulties. \\
DVs: School \\
performance \\
(reported 3
\end{tabular} \mid $\begin{gathered}\text { cognitive } \\
\text { difficulties in } \\
\text { which then } \\
\text { predicted their } \\
\text { poorer school } \\
\text { performance. } \\
\text { Thus, } \\
\text { children's } \\
\text { cognitive } \\
\text { difficulties } \\
\text { months later). }\end{gathered}$




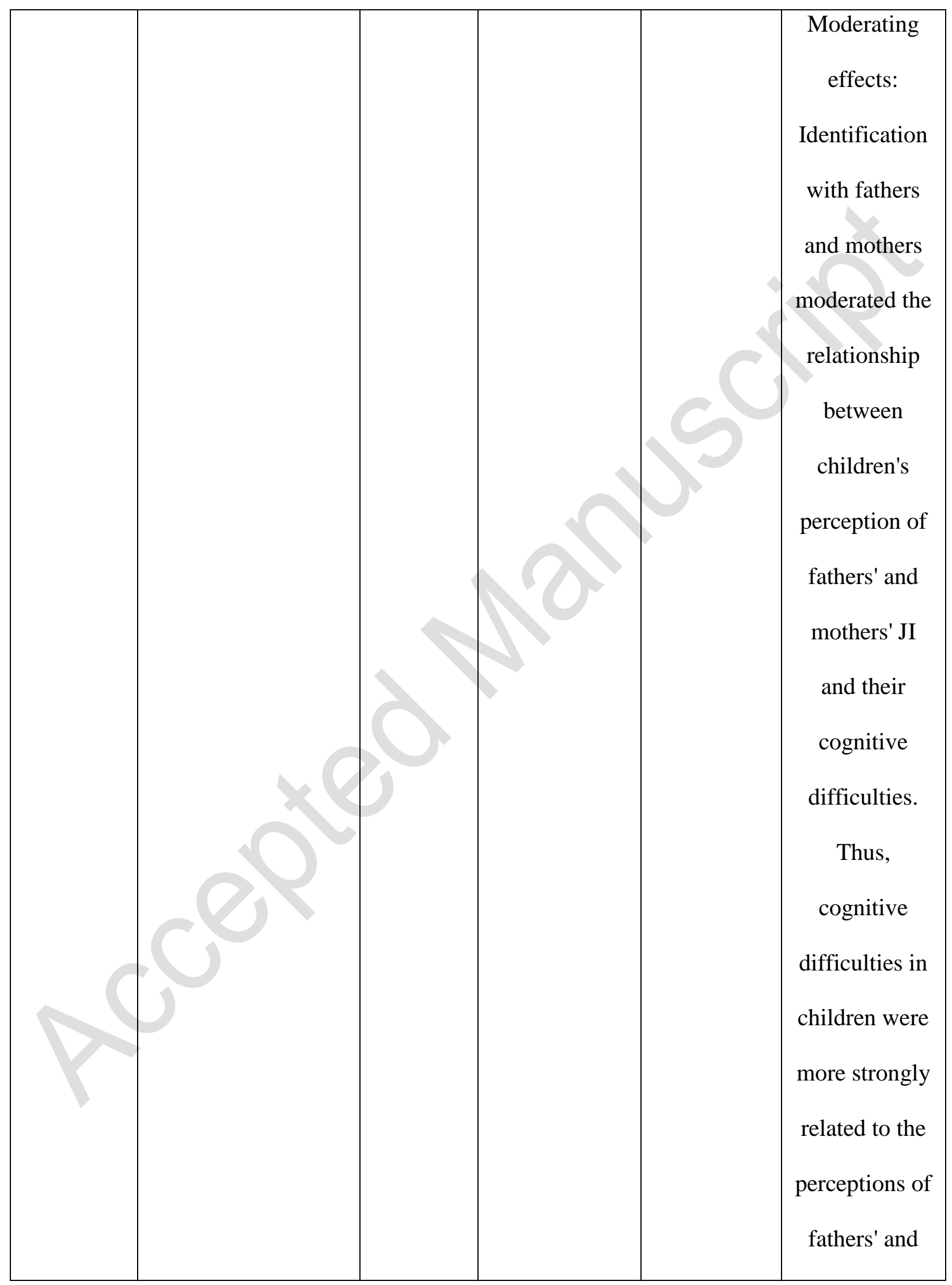




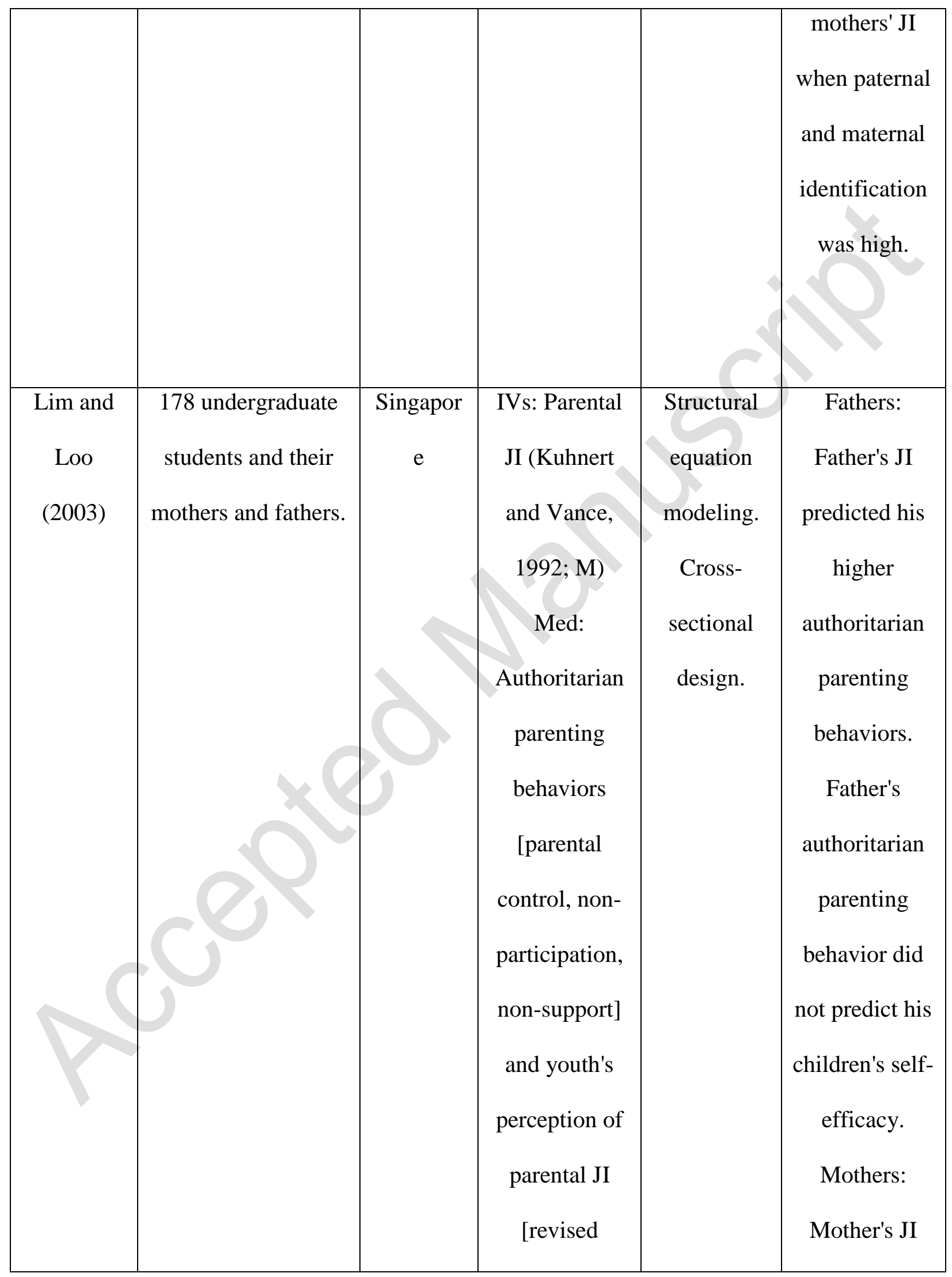




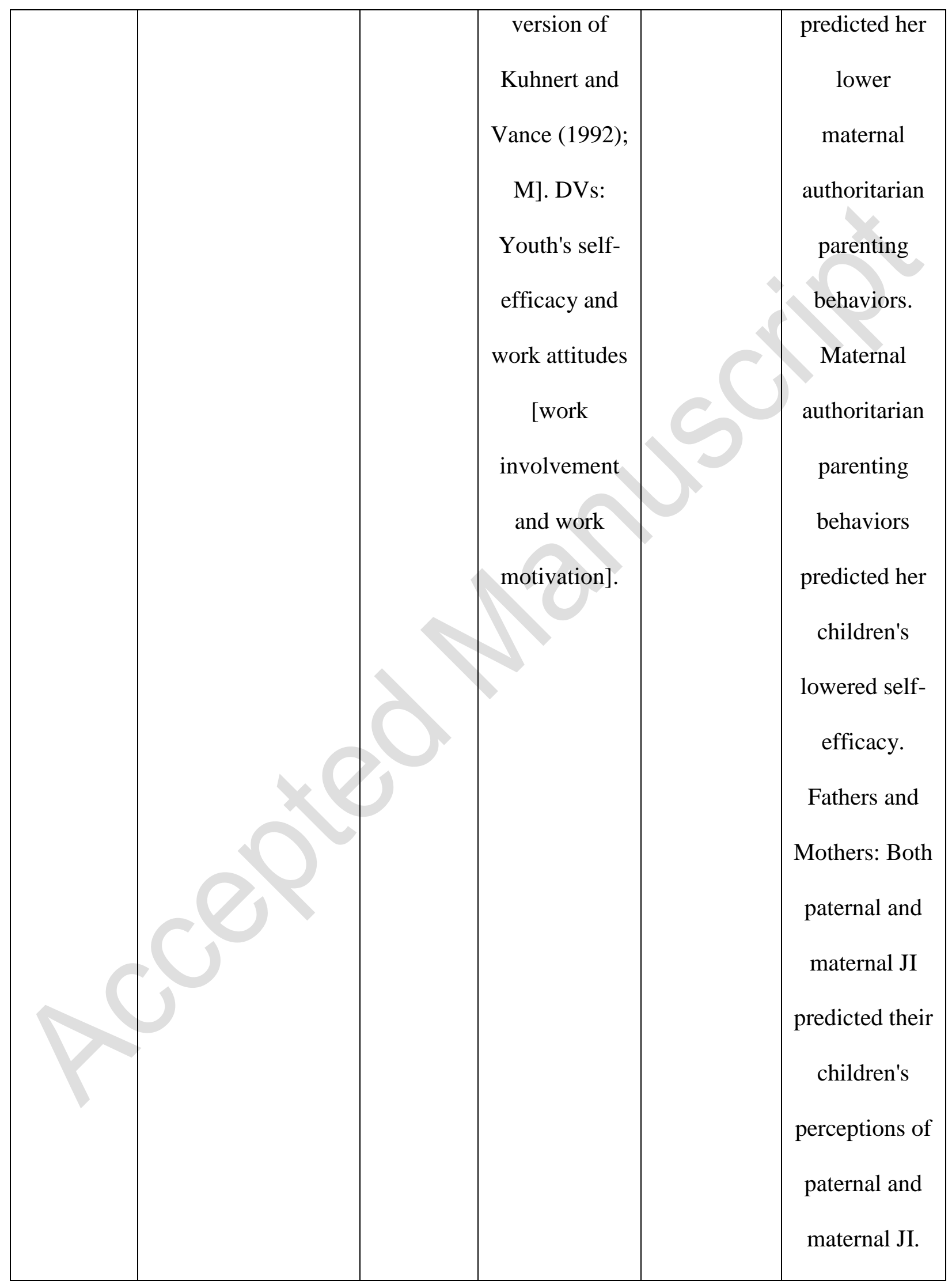




\begin{tabular}{|c|c|c|c|c|c|}
\hline & & & & & $\begin{array}{c}\text { Children's } \\
\text { perceptions of } \\
\text { paternal and } \\
\text { maternal JI } \\
\text { predicted their } \\
\text { lowered self- } \\
\text { efficacy and } \\
\text { children's } \\
\text { lowered self- } \\
\text { efficacy } \\
\text { predicted their } \\
\text { lowered work } \\
\text { attitudes } \\
\text { (work } \\
\text { involvement } \\
\text { and work } \\
\text { motivation). }\end{array}$ \\
\hline $\begin{array}{l}\text { Lim and } \\
\text { Sng } \\
\text { (2006) }\end{array}$ & $\begin{array}{l}185 \text { undergraduate } \\
\text { students and their } \\
\text { fathers and mothers. }\end{array}$ & $\begin{array}{l}\text { Singapor } \\
\text { e }\end{array}$ & $\begin{array}{l}\text { IVs: Paternal } \\
\text { and maternal } \\
\text { JI (Kuhnert \& } \\
\text { Vance, 1992]; } \\
\text { M). Med: } \\
\text { Paternal and }\end{array}$ & $\begin{array}{l}\text { Structural } \\
\text { equation } \\
\text { modeling. } \\
\text { Cross- } \\
\text { sectional } \\
\text { design. }\end{array}$ & $\begin{array}{l}\text { Fathers: } \\
\text { Father's JI } \\
\text { predicted his } \\
\text { money anxiety } \\
\text { (economic } \\
\text { stress). }\end{array}$ \\
\hline
\end{tabular}




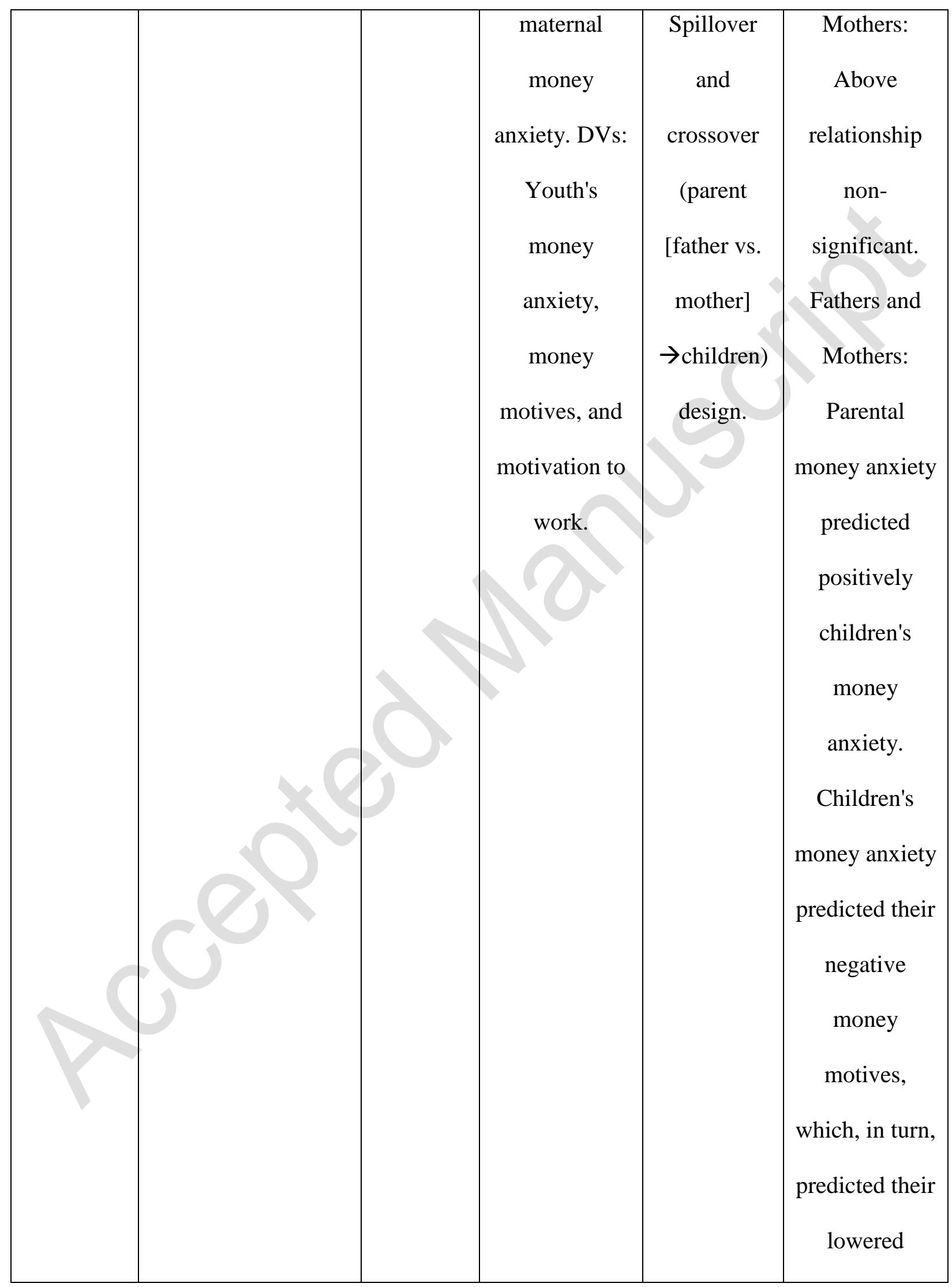




\begin{tabular}{|c|c|c|c|c|c|}
\hline & & & & & $\begin{array}{c}\text { intrinsic } \\
\text { motivation to } \\
\text { work } \\
\text { (children's } \\
\text { negative } \\
\text { money } \\
\text { motives acted } \\
\text { as a mediator). }\end{array}$ \\
\hline $\begin{array}{l}\text { Mauno } \\
\text { and } \\
\text { Kinnunen, } \\
\text { (1999a) }\end{array}$ & $\begin{array}{l}215 \text { married or } \\
\text { cohabiting dual- } \\
\text { earner couples. }\end{array}$ & Finland & $\begin{array}{c}\text { IVs: JI } \\
\text { (Hartley et al., } \\
\text { 1991; G) and } \\
\text { three other } \\
\text { work } \\
\text { stressors. } \\
\text { Med: Job } \\
\text { exhaustion } \\
\text { and } \\
\text { psychosomati } \\
\text { c symptoms. } \\
\text { DVs: Marital } \\
\text { satisfaction. }\end{array}$ & $\begin{array}{l}\text { Structural } \\
\text { equation } \\
\text { Modeling. } \\
\text { Cross- } \\
\text { sectional } \\
\text { design. } \\
\text { Spillover } \\
\text { and } \\
\text { crossover } \\
\text { (between } \\
\text { spouses) } \\
\text { design. }\end{array}$ & $\begin{array}{c}\text { JI predicted } \\
\text { marital } \\
\text { dissatisfaction } \\
\text { via job } \\
\text { exhaustion } \\
\text { and } \\
\text { psychosomati } \\
\text { c health } \\
\text { among dual- } \\
\text { earner } \\
\text { couples, but it } \\
\text { did not } \\
\text { crossover } \\
\text { between the } \\
\text { couples. JI }\end{array}$ \\
\hline
\end{tabular}




\begin{tabular}{|c|c|c|c|c|c|}
\hline & & & & & $\begin{array}{l}\text { had spillover } \\
\text { effects in both } \\
\text { couples on } \\
\text { marital } \\
\text { dissatisfaction } \\
\text { (Note. The } \\
\text { study focused } \\
\text { also on other } \\
\text { work stressors } \\
\text { than JI). }\end{array}$ \\
\hline $\begin{array}{l}\text { Stewart } \\
\text { and } \\
\text { Barling } \\
\text { (1996) }\end{array}$ & $\begin{array}{l}189 \text { fathers. } \\
\text { Teachers provided } \\
\text { ratings of children's } \\
\text { behaviors. }\end{array}$ & Canada & $\begin{array}{l}\text { IVs: Fathers } \\
\text { working } \\
\text { experiences } \\
\text { (JI, Vance \& } \\
\text { MacNeil, } \\
\text { 1990; G). } \\
\text { Med: Job- } \\
\text { related affect } \\
\text { (job } \\
\text { satisfaction, } \\
\text { negative job- } \\
\text { related mood } \\
\text { and job }\end{array}$ & $\begin{array}{l}\text { Structural } \\
\text { equation } \\
\text { modeling } \\
\text { (path } \\
\text { analysis). } \\
\text { Cross- } \\
\text { sectional } \\
\text { design. }\end{array}$ & $\begin{array}{c}\text { JI predicted } \\
\text { lowered job } \\
\text { satisfaction in } \\
\text { fathers (one of } \\
\text { three job } \\
\text { related } \\
\text { affects) but } \\
\text { their job } \\
\text { satisfaction } \\
\text { did not predict } \\
\text { their parenting } \\
\text { behaviors, nor } \\
\text { children's }\end{array}$ \\
\hline
\end{tabular}




\begin{tabular}{|c|c|c|c|c|c|}
\hline & & & $\begin{array}{c}\text { tension) and } \\
\text { parenting } \\
\text { behaviors } \\
\text { (punishing, } \\
\text { rejecting and } \\
\text { authoritative } \\
\text { behaviors). } \\
\text { DVs: } \\
\text { Children's } \\
\text { behaviors } \\
\text { (acting out, } \\
\text { shyness and } \\
\text { school } \\
\text { competence). }\end{array}$ & & $\begin{array}{l}\text { behaviors. } \\
\text { (No crossover } \\
\text { from fathers } \\
\text { to children). } \\
\text { (Note. This } \\
\text { study focused } \\
\text { also on other } \\
\text { work stressors } \\
\text { than JI.) }\end{array}$ \\
\hline $\begin{array}{c}\text { Westman } \\
\text { et al. } \\
\text { (2001) }\end{array}$ & $\begin{array}{l}98 \text { married couples } \\
\text { (Husbands = 98; } \\
\text { Wives = 98). }\end{array}$ & Israel & $\begin{array}{l}\text { IVs: JI (only } \\
\text { using revised } \\
\text { importance } \\
\text { and } \\
\text { probability } \\
\text { sub-scales } \\
\text { from Ashford } \\
\text { et al., 1989; } \\
\text { M), social }\end{array}$ & $\begin{array}{l}\text { Structural } \\
\text { equation } \\
\text { modeling. } \\
\text { Cross- } \\
\text { sectional } \\
\text { design }\end{array}$ & $\begin{array}{l}\text { Husband's JI } \\
\text { predicted his } \\
\text { wife's JI, thus } \\
\text { JI was a } \\
\text { shared } \\
\text { experience } \\
\text { between the } \\
\text { couples. For } \\
\text { only husband, }\end{array}$ \\
\hline
\end{tabular}




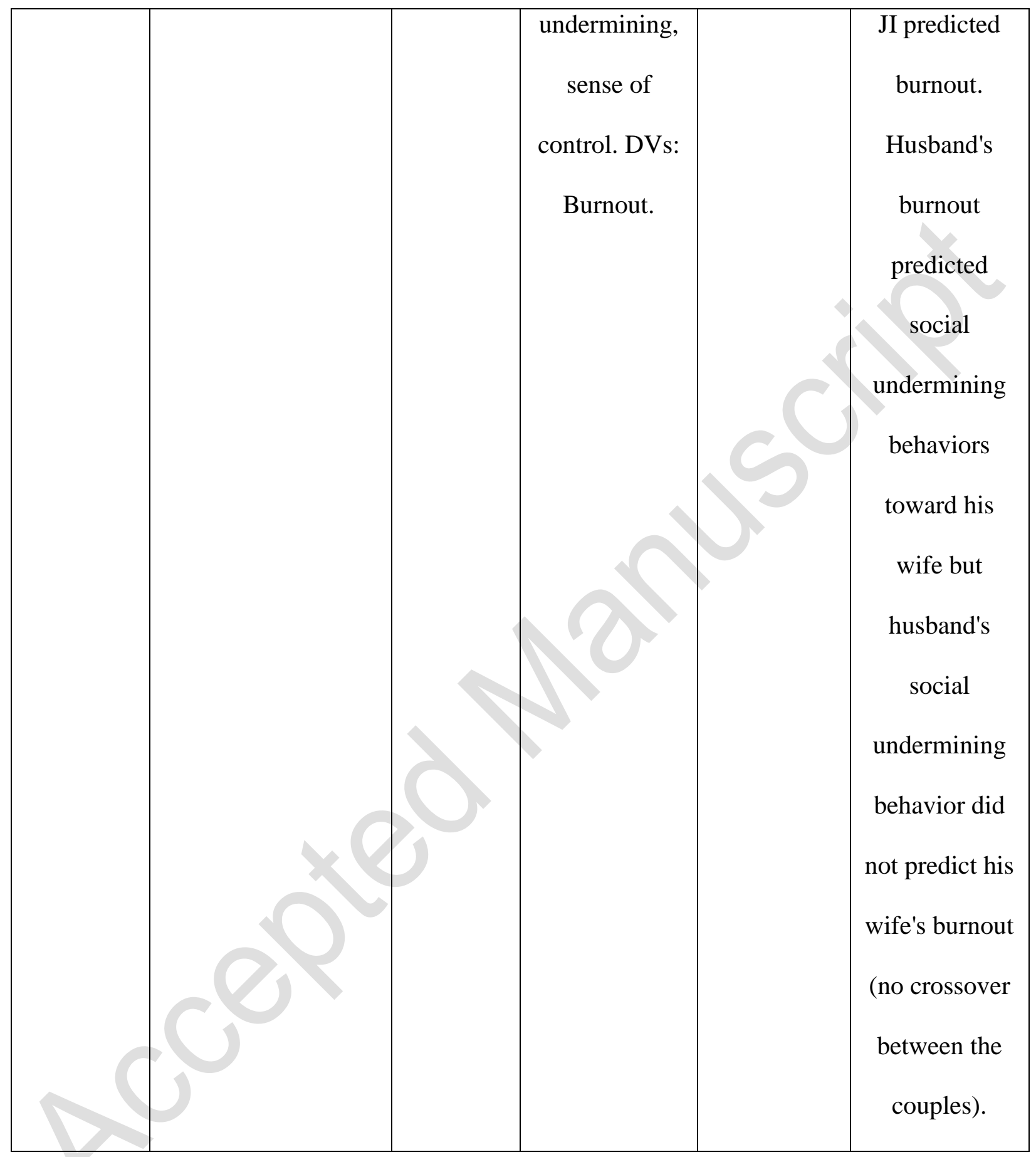




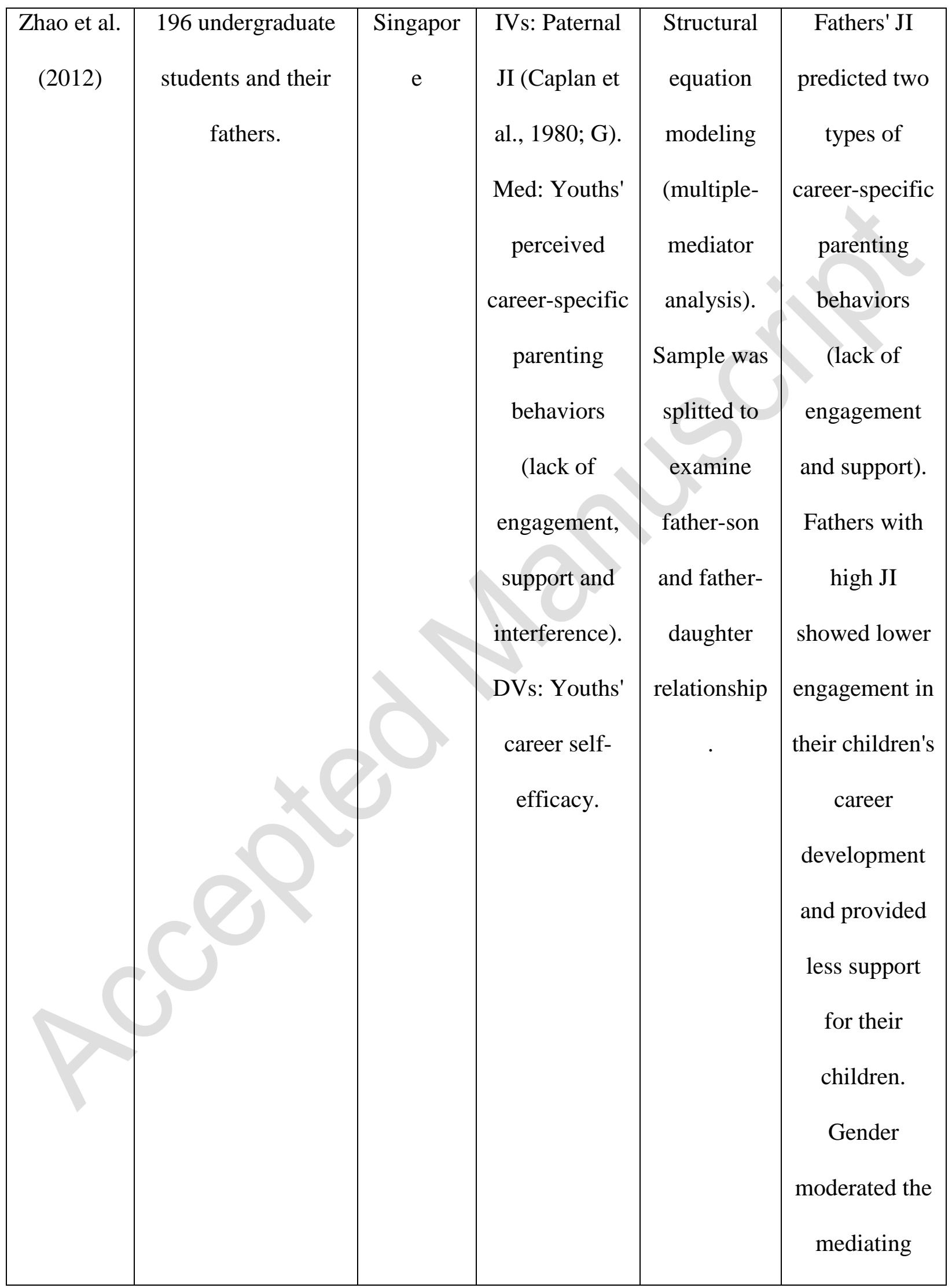




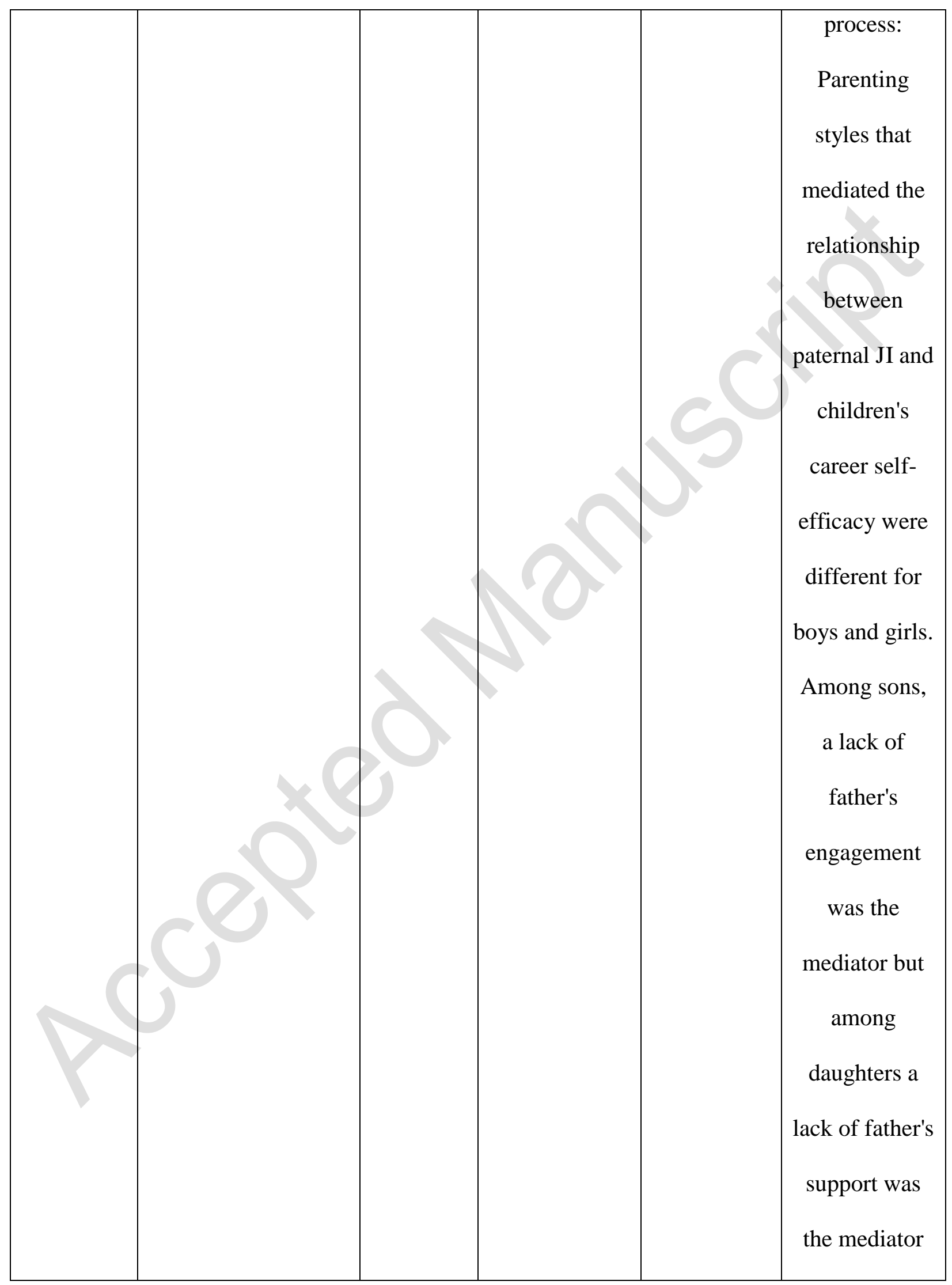




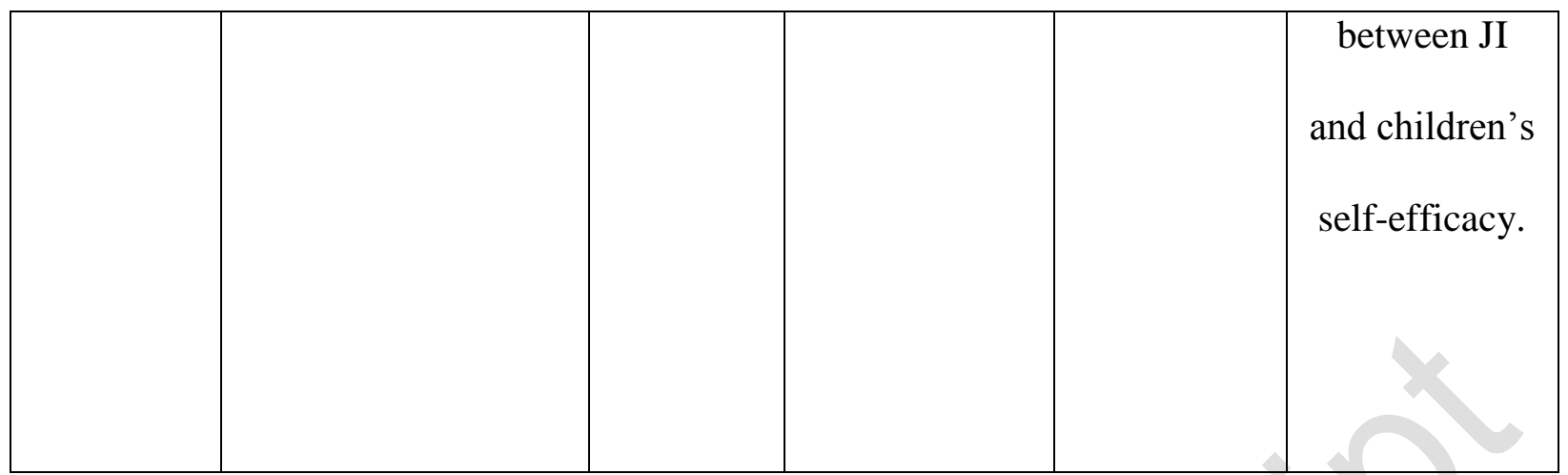

Note for abbreviation: JI = Job insecurity; G = Global measure of JI; M = Multidimensional measure of JI; IVs = Independent variables; Mod = Moderators; Med = Mediators; DVs = Dependent variables; Stat. Method = Statistical Methods. 